\title{
Hızlı Büyüyen KOBI'lerde İç Girişimcilik: Ankara İlinde Bir Araştırma (Internal Entrepreneurship in Fast Growing SME's: A Research in Ankara Province)
}

\section{Mürüfe ÖZTÜRK DUGAN iD a Nuray TOSUNOĞLU iD b}

a Ankara Hacı Bayram Veli Üniversitesi, Sosyal Bilimler Enstitüsü, Ankara, Türkiye, murufeozturk@gmail.com

b Ankara Hacı Bayram Veli Üniversitesi, İktisadi ve İdari Bilimler Fakültesi, Ankara, Türkiye. ngtosunoglu@gmail.com

\begin{tabular}{l}
\hline MAKALE BİLGİsi \\
\hline Anahtar Kelimeler: \\
KOBİ \\
Hılı Büyüyen KOBİ \\
Hılı Büyüme \\
İç Girişimcilik \\
Gönderilme Tarihi 6 Mart 2020 \\
Revizyon Tarihi 16 Haziran \\
2020
\end{tabular}

Kabul Tarihi 20 Haziran 2020

\section{ÖZET}

Amaç - Günümüz ekonomisi küresel, dinamik ve rekabetçi olduğundan işletmelerin hayatta kalmaları için işletme büyümeleri zorunluluk olarak değerlendirilmektedir. KOBİlerde büyüme tüm orta ve üst düzey yöneticileri kapsayan bir olgudur. KOBI'lerde girişimci; farkına varmadan ya da farkında olarak büyümeyi doğrudan etkileyen karar mekanizmasıdır. KOBI'lerde iç girişimcilik düzeyinin, işletmenin bu karar mekanizmasını doğrudan etkilediği ve hızlı büyümeyi sağladığı düşünülmektedir. Bu düşünceden hareketle bu çalışmanın amacı hızlı büyüyen KOBíler ile hızlı büyümeyen KOBİ'lerin orta ve üst düzey yetkililerinin iç girişimcilik düzeylerinin karşılaştırılarak farklılıklarının tespit edilmesidir.

Yöntem - Çalışmanın amacı doğrultusunda Ankara'da KOSGEB'e kayıtlı KOBI'lerden elde edilen veriler ile karşılaştırmalı nicel bir araştırma yapılmıştır. 429 işletmenin hızlı büyümeleri incelenerek, iç girişimcilik düzeyleri belirlenmiştir. Hızlı büyüyen işletmeler ile hızlı büyümeyen işletmelerin iç girişimcilik düzeyleri karşılaştırılmıştır. Analiz için t-testinden yararlanılmıştır.

Bulgular - Analiz sonucunca hızlı büyüyen KOBİlerin yenilikçilik ve proaktif davranış düzeylerinin hızlı büyümeyen KOBİlerden yüksek olduğu bulunmuştur.

Makale Kategorisi:

Tartışma - Araştıma kapsamında yer alan KOBİ'lerde yenilikçiliğin ve proaktif davranışın Araştırma Makalesi geliştirilmesi hızlı büyümeye destek olacaktır. Bu da makroekonomik olarak, istihdamda etkili bir artış ve küresel rekabette avantaj sağlayacaktır.

\begin{tabular}{|c|c|}
\hline ARTICLE INFO & ABSTRACT \\
\hline Keywords: & \multirow{8}{*}{$\begin{array}{l}\text { Purpose - Since today's economy is global, dynamic and competitive, the survival and growth of } \\
\text { firms are considered as necessities. Growth requires many middle and high level decisions for SMEs } \\
\text { Growth in SMEs is a phenomenon that covers all middle and senior managers. Entrepreneurs in } \\
\text { SMEs; it is a decision mechanism that directly affects growth without realizing it or being aware or } \\
\text { it. It is believed that the level of internal entrepreneurship in SMEs directly affects the decision } \\
\text { making process of the firm and enables rapid growth. From this point of view, interna } \\
\text { entrepreneurship will be able to provide support to government agencies and financial institutions } \\
\text { in the development of policies that encourage firm growth, particularly in the development of SME } \\
\text { growth strategies. With this in mind, the aim of this study is to determine the differences between } \\
\text { the level of internal entrepreneurship of medium and high level officials of fast-growing SMEs and } \\
\text { non-fast-growing SMEs. }\end{array}$} \\
\hline SME & \\
\hline Fast Growth SME & \\
\hline Fast Growth & \\
\hline Internal Entrepreneurship & \\
\hline & \\
\hline Received 6 March 2020 & \\
\hline Revised 16 June 2020 & \\
\hline Accepted 20 June 2020 & $\begin{array}{l}\text { Design/methodology/approach - For the purpose of the study, a survey was conducted in Ankara } \\
\text { with KOSGEB registered SMEs. Internal entrepreneurship levels were determined by examining the } \\
\text { rapid growth of } 429 \text { firms. Internal entrepreneurship levels of fast-growing firms and non-fast- } \\
\text { growing firms were compared. The t-test was used for analysis. }\end{array}$ \\
\hline \multirow[t]{2}{*}{ Research Article } & $\begin{array}{l}\text { Findings - As a result of the analysis, it is seen that the level of innovation and proactive behavior } \\
\text { of fast growing SMEs is higher than those that do not grow fast. }\end{array}$ \\
\hline & $\begin{array}{l}\text { Discussion - Within the scope of the research, innovation and proactive behavior development in } \\
\text { SMEs will support rapid growth. This will provide an effective increase in employment and an } \\
\text { advantage in global competition. }\end{array}$ \\
\hline
\end{tabular}

${ }^{1}$ Bu çalışma Doç. Dr. Nuray TOSUNOĞLU danışmanlığında, Mürüfe ÖZTÜRK DUGAN tarafından hazırlanan yüksek lisans tezinden uyarlanmıştır.

\section{Önerilen Atıf/ Suggested Citation}

Öztürk Dugan, M., Tosunoğlu, N. (2020). Hızlı Büyüyen KOBi'lerde İç Girişimcilik: Ankara İlinde Bir Araştırma, İşletme Araştırmaları Dergisi, 12 (2), 2061-2079. 


\section{GİRIŞ}

Ülke ekonomisini canlı tutan Küçük ve Orta Büyüklükteki İşletmeler (KOBI'ler), ülkelerin sosyal ve ekonomik gelişimi açısından çok büyük öneme sahiptirler. KOBI'ler yeni istihdam alanları yaratmadaki katkıları, esnek yapıları sayesinde değişikliklere uyum sağlama yetenekleri ve sosyal kalkınmaya etkileri nedeniyle ülke ekonomilerinin temel dinamiği haline gelmişlerdir. Her geçen gün bu işletmelerin üretim, ihracat, katma değer ve yatırım içindeki payı artarak önemli büyüklüklere ulaşmaktadır. Bütün ekonomilerin temel dinamiğini oluşturmalarına rağmen, bugün literatürde üzerinde görüş birliği sağlanmış bir KOBİ tanımı bulunmamaktadır. Bununla birlikte $\mathrm{AB}$ ve OECD tanımlamaları üst tanımlama olarak kabul edilmektedir. Bu tanıma göre 1-249 çalışana sahip, yıllık cirosu 50 milyon Euronun altında olan işletmeler KOBİ'dir.

Dünya ve ülke ekonomisinde KOBİlerin payı ve sayısı ülkeden ülkeye değişiklik göstermekle birlikte dünya genelinde \%96'nın üzerinde olduğu gözlenmektedir (Gümüş, 2007:237). Bu büyüklük elbette kaçınılmaz bir şekilde rekabeti ve bununla birlikte sürdürülebilir bir büyümeyi gerekli kılmıştır. KOBİ'lerin rekabette avantajı yakalamaları ve sürdürebilir büyümeyi sağlamaları için, yenilikçilik ve pazarlama yeteneklerini yapılandırıp performanslarını artırabilmeleri gerekmektedir. Performansı sağlamak ve sonrasında artırmak ise büyük ölçüde girişimcinin vizyonu ve kabiliyeti ile ilişkilidir.

Türkiye'de KOBíler tüm işletmelerin \%99.9'unu oluşturmaktadır. Türkiye Girişimcilik Stratejisi Eylem Planı 2015 - 2018 raporunda yer alan, "İş Kayıtlarına Göre Girişim Sayıları" çalışması sonuçlarında 2013 yılında ülkemizde 3.529.541 işletmenin faaliyette olduğu görülmektedir. Bu işletmelerin 3.303.210'u Mikro (\%93,6), 190.554 'ü Küçük $(\% 5,4)$ ve 30.567'sı Orta (\%0,9) ölçekli olmak üzere toplamda 3.524.331'i sadece çalışan sayısı kriteri dikkate alındığında KOBİ'dir (\%99,9). Türkiye'de ihracatın \%59,2'si, ithalatın ise \%39,9'u KOBI'ler tarafından gerçekleştirilmiştir (Türkiye Girişimcilik Stratejisi Eylem Planı 2015 - 2018).

2000'li yıllardan itibaren Hızlı Büyüyen KOBİ kavramı gündeme gelmiştir. Bu yeni kavramla birlikte diğerlerinden daha iyi performans gösteren işletmelerin farklı bir şekilde ele alınması gerektiği fikri ortaya çıkmıştır. Hızlı büyüme, yıllık ortalama büyümesi üç yıl boyunca yılda \% 20' den fazla olan ve faaliyetine on veya daha fazla çalışan ile başlamış olan tüm işletmeleri ifade etmektedir (European Commission, 2009). Hızlı büyüyen işletmeler iş olanakları oluşturma anlamında ülke ekonomileri için lider durumdadır. Bu sebeple araştırmacılar ve siyasetçiler tarafından ilgi çeken bir konu olmuştur (Ferrando ve diğerleri, 2019). Hızlı büyüme, işletme meşruiyetinin sağlanarak piyasada kalıcılığın temin edilmesini, ölçek ekonomilerinin oluşturulmasını, yatırım sermayesinin çekilmesini ve kârlılığın arttırılmasını sağlar (Nixon-Nicholls, 2005).

Hızlı büyüme ile ilgili literatür incelendiğinde bu konudaki ilk çalışmalardan biri sayılabilecek çalışmanın Smallbone ve diğerleri (1995) tarafından yürütüldüğü görülebilir. Çalışmada 1979-90 yılları arasında hızlı büyüme sağlayan bir grup imalatçı KOBİ'nin özellikleri ve stratejileri, zayıf performans gösteren işletmelerle karşılaştırılmıştır. Nixon-Nicholls (2005), liderlik ve yönetim uygulamalarının, KOBİ'lerin hızlı büyümesinde ve yüksek performansın sürdürülebilirliğinde kilit faktörler olduğunu belirterek, Kanada'da hızlı büyüme sağlamış girişimcilerden 15 CEO ile görüşmeler yapmıştır. O'Regan ve diğerleri (2006), hızlı büyüme alanındaki literatürün çoğunluğunun büyük firmalara odaklandığını, yüksek büyüme gösteren küçük firmalarla ilgili araştırmaların az sayıda olduğunu belirtmişlerdir. Çalışmalarında KOBİlerin üretimindeki hızlı büyümenin itici güçlerini araştırmışlardır. Autio ve diğerleri (2007), yüksek büyüme gösteren işletmeler ve hızlı büyümenin KOBİ Politikası ve İnovasyon Politikası ile ilişkisi hakkında kapsamlı bir inceleme sağlayacak çok az çalışma yapıldığını vurgulayarak, yüksek büyüme gösteren firmaları desteklemek için etkili politika önlemlerini tanımlamaya çalı̧̧ışlardır. Henrekson ve Johansson (2010), net istihdam büyümesinin, küçük ve genç olması gerekmeyen ve hızla büyüyen birkaç işletme tarafından sağlandığını belirtmişlerdir. Bu işletmeler olağanüstü iş yaratıcıları olarak görülmektedir. Bjuggren ve diğerleri (2013) literaürdeki ampirik çalışmaların, net iş büyümesinin çoğunun hızlı büyüme gösteren az sayıda işletmeden kaynaklandığını göstermekte olduğunu belirtmişlerdir. Çalışmalarında 1993-2006 yılları arasında İsveç'teki tüm özel işletme verilerini kullanarak aile sahipliğinin hızlı büyüme için önemli olup olmadığını analiz etmişlerdir. Vértesy ve diğerleri (2017), hızlı büyümeye ilişkin tanımın belirsizliğinden bahsederek yenilikçi girişimcilerin Avrupa işletme popülasyonundaki payını ölçmüşler ve hızlı büyüme ile ilgili farklı tanımların bu payları nasıl etkilediğini test etmeyi amaçlamışlardır. Hızlı büymeye ilişkin tanımdaki belirsizliği gidermek için yeni bir metodoloji önermişlerdir. Günümüze gelindiğinde literatürde karşılaşılan üç çalışmada hızlı büyümenin, finansman, AR-GE, ihracata olan yatırım, verimlilik ve istihdam açısından incelendiği gözlenmiştir (Ferrando 


\section{M. Öztürk Dugan - N. Tosunoğlu 12/2 (2020) 2061-2079}

vd., 2019; Huang, 2019; Monteiro, 2019). Hızlı büyüme konusuna olan ilginin gittikçe arttığı literatürden de görülmektedir. Henrekson ve Johansson'un (2010) çalışması 7 Kasım 2013'te 251 alıntıya sahipken (Coad, 2014), 30 Kasım 2019'de yapılan aramada alıntı sayısının 965'e çıtığı görülmüştür. Bu değişim konuya olan ilginin ne ölçüde arttığını göstermektedir. Uluslararası alanda çok sayıda çalışma olmasına karşın hızlı büyüyen KOBİ kavramı üzerine Türkçe literatürde sınırlı sayıda çalışmaya rastlanmıştır. Taymaz ve diğerleri (2008), Güzel ve Giray (2014) ve Yücelen (2017) hızlı büyüyen KOBİ kavramılla ilgili çalışmalar yapmışlardır. Bunun yanı sıra 2016 yılında KOSGEB tarafından açıklanan destek programında ilk kez bu kavrama değinilmiştir.

Hızlı büyümeyi etkileyen faktörler, işletmenin kendi içinde yönetebileceği iç faktörler (yenilikçilik, organizasyonel beceriler, işletme sahipliği) olabileceği gibi, uyum sağlaması gereken dış faktörler (çevre, eticaret, stratejik yönelimler) de olabilmektedir (O'Regan ve diğerleri, 2006:32). Hızlı büyümenin iç faktörleri incelendiğinde; pazara yeni fikirler getirmeyi amaçlayan kapsamlı faaliyetlere, yürütülen faaliyetin çalışanlar tarafından sahiplenilmesine ve yönetsel kapasitenin dinamik olarak karar verme politikalarına bağlı olduğu görülmüştür. Bu faktörlerin iç girişimciliğin tanımlarında yer alan "yenilikçi", "fırsatları kovalayan", "organizasyonel becerileri yüksek" kavramları ile benzerlik taşıdığı fark edilmiştir. Buradan hareketle hızlı büyüme gerçekleştiren KOBI'lerin iç girişimcilik düzeylerinin ne olduğu ve hızlı büyümeyen KOBİlerle farklılık gösterip göstermediği sorusu ortaya çımıştır. Bu soru bu çalışmanın ana problemini oluşturarak araştırma buna uygun bir biçimde tasarlanmıştır. Çalışmanın amacı hızlı büyüyen KOBİlerin iç girişimcilik düzeylerinin, hızlı büyümeyen KOBI'lerden farklı olup olmadığını belirlemek ve varsa bu farklılıkları ortaya koymaktır.

Çalışmada öncelikle hızlı büyüme ve iç girişimcilik kavramları tanıtılacaktır. Hızlı büyüyen KOBİ'lerin iç girişimcilik düzeylerinin diğer KOBİ'lerden farklılı̆̆ını incelemek amacıyla Ankara'da KOSGEB'e kayıtlı KOBİ'lerden alınan veriler ile gerçekleştirilen karşılaştırılmalı nicel araştırma, yöntem bölümünde verilerek, elde edilen bulgular sonuç bölümünde tartışlacaktır.

\section{2. İ̧SLTMELERDE HIZLI BÜYÜME}

Hızlı büyüyen işletmeler ekonomik büyümeye oluşturdukları katkı ve işsizliği azaltıcı yöndeki etkisi nedeniyle son yıllarda ilgi çeken konular arasına girmiştir. EUROSTAT ve OECD tarafından yapılan tanıma göre, on ve üzerinde personel ile faaliyete başlayan ve son üç yıl içinde yıllık ortalama asgari \%20 oranında istihdam artışı sağlayan işletmeler hızlı büyüyen işletmelerdir (European Commission, 2009). Hızlı büyüyen işletmelerle ilgili OECD (2010) raporunda önerilen tanım ise, "Yıllık ortalama büyümesi, üç yıl boyunca yılda $\%$ 20'den fazla olan ve faaliyet başlangıcında on veya daha fazla çalışanı olan beş yaşına kadar olan tüm işletmeler" biçimindedir. Bu tanımlar, endüstriler arasındaki büyüme oranlarındaki farklılıkları dikkate almamaktadır. Örneğin; İspanya ekonomisinde 1998 - 2000 yılları arasındaki hızlı büyüme, imalat işletmelerinde ortalama \%10, hizmet işletmelerinde ise ortalama \%12 lik bir büyüme sağlamıştır. Bu nedenle, Moreno ve Casillas (2007), OECD tanımına alternatif bir yaklaşımla hızlı büyümeyi, sektör medyanının \% 100' ünün üzerinde üç yıllık bir büyüme oranı olarak tanımlamışlardır. Bu yaklaşım, sektördeki büyüme oranlarındaki değişimin zorluğunu ortadan kaldırmaktadır (Organisation for Economic Co-operation and Development, 2010).

KOSGEB 2016 yılında “Hızlı Büyüyen KOBİlerde Kapasite Geliştirme” adlı bir proje teklif çağrısında bulunmuştur. Bu çağrıda yer alan başvuru koşullarına göre; en az 3 yıllık ticari geçmişi olan, asgari 5 personele sahip, son 2 yılda istihdam veya net satış hasılatı ortalamasında en az $\% 20$ artışa sahip ve net satış hasılatı asgari 500.000 TL olan KOBİ'ler, hızlı büyüyen KOBI'dir (KOSGEB, 2016).

Yukarıdaki açıklamalardan da görüldüğü gibi literatürde hızlı büyüyen işletmelerin tanımı konusunda farklı görüşler yer almaktadır. Buna karşın büyümenin ölçümü ile ilgili üç temel değişken bulunduğu görülmektedir. Birinci değişken büyümenin neye göre tanımlanacağı (satışa göre, karlılığa göre, personel sayısına göre), ikinci değişken büyümenin periyodu (aylık, yıllık, 5 yıllık, vb.), üçüncü değişken ise hesaplama metodudur (kesin, bağıl veya logaritmik) (Davidsson ve diğerleri, 2006).

Hızlı büyümenin ön plana çıkmasının nedeni; verimlilikten uzak, ürün ve hizmetlerde gelenekçi yöntemlere bağlı, teknolojik gelişmelere ilgi duymayan ve gelişmelerin hızını ön göremeyen işletmelerin yerine, daha dinamik ve yenilikçi işletmelerin desteklenmesi gerektiğini savunan görüşün ağırlık kazanmaya başlamasıdır. 
Araştırmalar girişimlerin yeni istihdam yarattığını, yeni ürün ve hizmetler geliştirdiğini ve bu ürün ve hizmetlerin yurtiçi ve yurtdışı pazarlara sunulmasıyla başarı elde edilidiğini göstermektedir (Tonge ve diğerleri, 1998). Hızlı büyüyen işletmelerin net istihdam artışına katkısı özellikle durgunluk dönemlerinde yüksektir (European Commission, 2009). KOBİ'ler istihdam maliyetlerinin düşük olmasından dolayı avantaja sahiptirler. Dünya Bankası verilerine göre, KOBI'lerde bir kişilik iş alanı oluşturma maliyeti büyük işletmelere kıyasla üçte biri oranındadır. Bu nedenle KOBİler işssizliğin yüksek ve sermayenin az olduğu ülkelerde çok daha önemlidir (Öztürk 2007; Ulusoy ve Akarsu, 2012).

Dünyada hızlı büyüyen işletmeler yenilikçilikte, verimliliği artırmada ve ekonomik performans göstergelerini olumlu etkilemede temel işletmeler olarak kabul edilmektedir (Mason, Bishop ve Robinson, 2009; Güzel ve Giray, 2014:35). KOBİ'lerin ekonomiye katkıları göz önüne alındığında hızlı büyüyen KOBİler de dikkat çekmeye başlamıştır. KOBİ'ler 1970'lerde temel Avrupa Birliği sınıflandırma sistemi kullanılarak tek bir homojen grup olarak görülmekteydiler. Fakat zamanla, KOBİ'lerin, güçlü olduğu alanlar, yeni müşteri edinme yöntemleri, yeni ürünler/hizmetler geliştirmeleri ve büyümek için finansman sağlama çabaları bakımından farklı oldukları gözlemlenmiştir. Bu nedenle hızlı büyüyen KOBI'ler adında bir sınıflandırma ihtiyacı doğmuştur (Brown ve Lee, 2014). Türkiye imalat sanayi verilerine göre, 1981-1991 döneminde çoğu KOBİ tanımı içerisinde yer alan 6,000 yeni işletme kurulmuştur. Yeni işyerlerinde kuruluş yılında çalışan kişi sayısı 330,000'dir. Bu işyerlerinin yarısı ancak 10 yıl yaşayabilmiş, diğer yarısı da 10 yıllık dönemde kapanmıştır. İşyerlerinin yarısının kapanmasına karşın, ayakta kalan işyerlerinde 10 yıl sonra çalışan sayısı yaklaşık 300,000 kişiye ulaşmıştır. Bu dönemde büyüyen işletmeler, kapanan işletmelerdeki istihdam kaybını büyük oranda telafi etmişlerdir. Ayakta kalan yaklaşık 3,000 işletmenin en hızlı büyüyen \%10'u seçilmiş ve bu 295 işletmenin istihdama katkısı saptanmıştır. Hızlı büyüyen 295 işyeri 10 yılda yaklaşık 120,000 kişiye istihdam sağlamıştır. 1980-2001 döneminde imalat sanayinde yılda çalışan ortalamasının yaklaşı 1 milyon kişi ve yıllık istihdam artış oranının \% 1 olduğu göz önüne alındığında, hızlı büyüyen 295 işyerinin toplam istihdam artışının yarısını gerçekleştirdiği anlaşılmaktadır (Taymaz ve diğerleri, 2008). Tüm bu araştırmalar göstermektedir ki hızlı büyüme günümüzde gerek mikro ölçekli ekonomiler için gerekse diğer ülke ekonomileri için çok önemli bir kavram haline gelmiştir.

\subsection{Hizh Büyüme Faktörleri}

İşletmelerde hızlı büyümeyi sağlayacak tek bir faktör bulunmamaktadır. Yönetim ekibinin tecrübeleri, yalnız bir girişimci yerine ekip olarak yapılan başlangıçlar, iş stratejisi, pazar konumlandırma faaliyetleri ve insan kaynakları yöntemleri her işletmede farklılık göstermektedir. Bu farklılıklara rağmen hızlı büyüme gösteren işletmelerde başarılı olunması gereken temel faktörler de mevcuttur (Güzel ve Giray, 2014). Hızlı büyüyen KOBİlerin başarılı olmasına etki eden unsurlar işletme bünyesi içerisinde gerçekleşen iç faktörler ile işletme dışında meydana gelen dış faktörler olmak üzere Şekil 1'de görülebileceği gibi sınıflandırılır ( $\mathrm{O}^{\prime}$ Regan ve diğerleri, 2006).

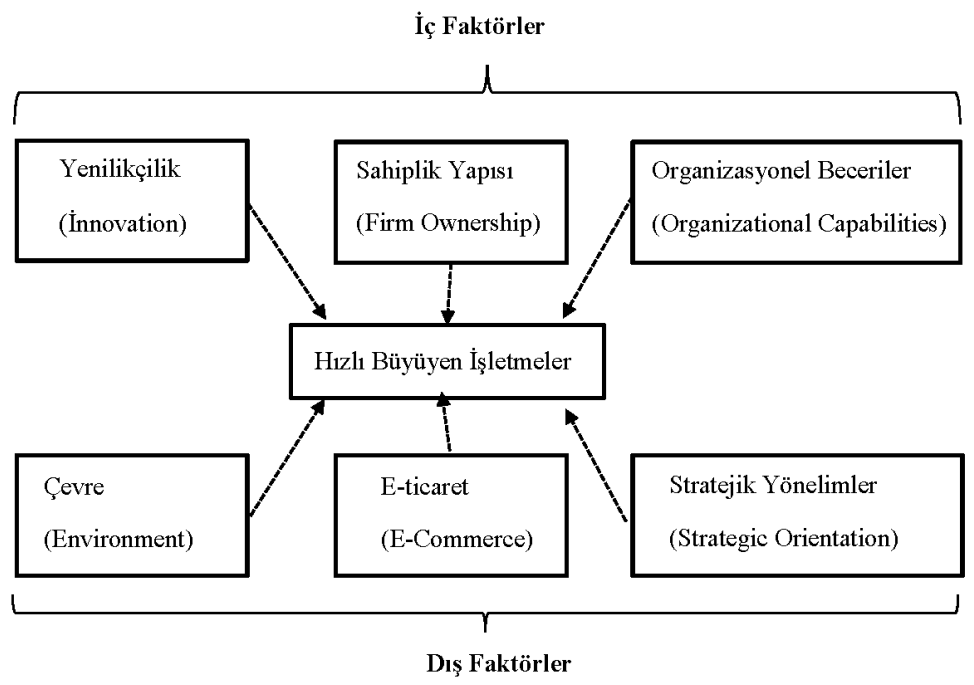

Şekil 1. Hızlı Büyüme Faktörlerinin Kavramsal Modeli

Kaynak: O’Regan ve diğerleri, 2006 


\section{M. Öztürk Dugan - N. Tosunoğlu 12/2 (2020) 2061-2079}

\subsubsection{Hızlı büyümenin iç faktörleri}

i. Yenilikçilik; ürün/hizmet faaliyetini iyileştirmek, yeni yöntemler geliştirerek üretim/hizmet sürecini farklılaştırmak veya yeni ürün/hizmet oluşturulmasını kapsar. Bu süreç ticari hedeflerden bağımsız bir şekilde sürdürülemez. En basit tanımıyla yenilikçilik, yeni fikirleri geliştirmek ve bunları uygulamaktır (Dengiz ve Belgin, 2007). OECD-Eurostat Oslo Kılavuzu (2005)'na göre ürün, süreç, pazarlama ve organizasyonel olmak üzere dört tür yenilikçilik faaliyetinden bahsedilebilir (Vértesy ve diğerleri, 2017). Ürün yenilikçiliği, yeni veya önemli ölçüde geliştirilmiş mal veya hizmetleri kapsamaktadır. Önemli ölçüde geliştirilmiş kavramı, üründeki yazılım, kullanıcı dostu olma, ürünün içerisindeki bileşenler, malzemeler ve diğer işlevsel özelliklerdeki iyileştirmeleri içerir (Vértesy ve diğerleri, 2017). Süreç yenilikçiliği yeni ekipmanların, yazılımların ve belirli tekniklerin ve prosedürlerin uygulanmasıyla ilgilenir. Yeni ya da önemli ölüçüde değiştirilmiş ürün ve hizmetlerin birim maliyetlerini düşürmek ya da kalitelerini artırmak için üretim ya da tedarik metotları kapsayan yenilikçilik, süreç yenilikçiliğidir. Pazarlama yenilikçiliği ürünlerin kabul edilebilirliğini artırmak için ürün tasarımında, paketlemede, ürün konumlandırmada, ürün tutundurma faaliyetlerinde ve fiyatlamada yapılan önemli değişiklikler ve dönüşümler ile pazarlamaya yeni ve farklı bir yön verilmesini içermektedir (Tüfekci ve Tüfekci, 2014). Organizasyonel yenilikçilik ise genel olarak tek boyutlu bir olgudur. İşletmelerin teknolojik, idari, ürün ve süreç gibi farklı yenilikçilik yaratabilecekleri alanlarda, yenilikçilik uygulamasına olan eğilimi ifade eder (Salavou ve diğerleri, 2004).

ii. Sahiplik yapısı, işletmelerin performansını etkileyen en önemli değişkenlerdendir. KOBì'ler çoğunlukla aileye ait işletmelerdir, bu nedenle girişimcilerin kendilerine yakın olan kişileri çalıştırma eğilimi yüksektir; bu da işletme sahipliğini işletmenin kontrolünü yürüten bireyden ayırmayı neredeyse imkânsız hale getirir. Ek olarak, işletme finansmanı ile girişimcinin finansmanı arasında ayrım yapmak zorlaşır (Adu-Darko, 2017: 46). Küçük işletmelerde aile sahipliğinin hızlı büyüyen işletme olma yolunda olumsuz etkisi bulunmaktadır (Bjuggren ve diğerleri, 2013). Yabancı ortaklı sahiplik yapısının, işletme büyümesi üzerinde, yabancı ve yerli tedarikçiler arasındaki bağları kuvvetlendirdiğinden, hızlandırıcı bir görevi bulunmaktadır (Erkan, 2015).

iii. Organizasyonel beceriler; işletmelerin iç çevresine odaklanarak dış etmenlere karşı rekabet üstünlügünü sağlayabilme yetenekleri, işletmenin işlerini daimi olarak geliştirmek amacıyla yeni üretim faaliyeti oluşturabilmeleri için yönetsel kapasitenin karar verme politikaları ve uygulamalarıyla ilişkili dinamik alışkanlıklardır. Organizasyonel beceriler yöneticilik, teknik ve çıktı bazlı olmak üzere üç ana başlık altında incelenir (Iraz ve diğerleri, 2016). Yöneticilik becerileri, işletme için stratejik bir vizyon oluşturabilme, bir kimlik yaratabilme, oluşturulan kimlik ve vizyonun organizasyon içerisinde kavranmasını sağlama ve çalışan personelini bunları başarmaya teşvik edebilme yeteneğine sahip olma becerileridir (Lopez ve diğerleri, 2006; akt. Iraz ve diğerleri, 2016). Teknik beceriler, etkili yazı ve raporlama tekniklerine hakim olma, mesleki yeterlilikte olma, işin gereklilikleri arasındaki teknik donanıma sahip olma, bilişim ve iletişim sistemlerini kullanabilme ve yönetme, etkili iletişim kurabilme, etkili ilişkiler geliştirebilme, ekip kurabilme ve ekibi yönetebilme becerisidir (Yıldırım ve diğerleri, 2011). Çıktı bazlı beceriler ise organizasyondaki üretim veya hizmet esnasında kullanılan girdilerin çıtılara dönüştürülme aşamasında ortaya konulan becerilerdir (Iraz ve diğerleri, 2016).

\subsubsection{Hızlı büyümenin dış faktörleri}

i. Çevre, genel anlamıyla faaliyet halindeki işletmeyi fiili olarak etkileyen ve potansiyel olarak etkileyebilecek tüm faktörleri temsil eder. Günümüzde işletmeler; çevrelerinde var olan kaynaklardan girdiler alan ve hedeflerine ulaşabilmek amacıyla bu girdileri çıtılara çeviren bir sistem olarak görülebilir. Bu nedenle işletmelerin devamllıklarını sürdürebilmesi, uzun dönem sektörde yer alabilmeleri çevrelerinde yer alan dinamiklerle uyum kabiliyetlerine bağlıdır. Çünkü çevrede artan karmaşıklığa duyarsız kalmak ve değişimin getirdiği belirsiz ortam, işletmeler için kötü sonuçlar doğurabilir. Bu nedenle işletmeler çevrelerine duyarlı olmayı ve çevreyle daha büyük uyum içinde olmayı zorunluluk haline getirmelidir (Naktiyok ve Kök, 2006).

ii. E-ticaret, işletmelerin ticari faaliyetlerinin geleneksel dağıtım kanallarından elektronik dağıtım kanallarına kaydırılmasıdır (Soydal, 2006). Ticaret süreci üç temel aşamaya ayrılabilir: Üretici ve tüketiciler veya alıcı ve satıcıların buluşması; iki taraf arasında sözleşmenin onaylanması ve bunun ardından sipariş ve ödeme işlemlerinin gerçekleştirilmesi; alınan hizmet veya ürünün dağıtımı. Belirtilen temel aşamalardan birinin veya tamamının elektronik ortamda gerçekleşmesi, yapılan işlemin e-ticaret kapsamında değerlendirilmesi için yeterlidir (Kalaycı, 2008). E-ticaret, işletmeler arası verimliliğin artırılması ve maliyetlerin azaltılmasında 


\section{M. Öztürk Dugan - N. Tosunoğlu 12/2 (2020) 2061-2079}

önemli rol oynamaktadır. Bilgisayar desteği ile stok yönetimi açısından depo için ihtiyaç duyulan alanda azalma olmaktadır. Ayrıca, tüketici eğilimlerinin izlenebilmesi ve verilerden anlam üretebilme kabiliyeti ile tüketicinin ilgisini çekebilecek yeni ürünlerin keşfi ve müşterinin sipariş verme kararı almasında kolaylıklar sağlayarak işletme açısından satışlarda artış sağlar.

iii. Stratejik yönelimler, uzun vadeli rekabet üstünlüğünün sağlanması ve sürdürülebilmesi amacıyla bir işletmedeki personelin inançlarını, değerlerini, normlarını temel alan ve işletme iş stratejisi ve vizyonuna uygun ortak davranışların oluşturulmasını sağlayan davranışsal eğilimler olarak tanımlanmıştır (Bulut ve diğerleri, 2008; Usta, 2011). Stratejik yönelim, yöneticilerin değişen çevresel koşullar altında çevreyi algılama ve değişen çevreye verdikleri tepkiyi gösterir. Örneğin, tüketici ihtiyaçları hakkında içgörü, rakiplerin yeteneklerini yakın takip, rakiplerle kıyaslama ve tedarikçilerle ilgili bilgi toplamanın işletmede bir kültür haline gelmesini sağlamak stratejik yönelimi etkili kullanmanın bir yoludur ve organizasyonun yeteneklerini geliştirmektir (Usta, 2011).

\subsection{Hızlı Büyüyen KOBI'lerin Gelişim Evreleri}

Yenilikçi ve hızlı büyüyen bir işletme, ürün fikir arayışından pazarda var olana dek çok sayıda aşamadan geçmektedir. Süreç boyunca, büyümeye devam edebilmek için farklı basamaklarda farklı gereklilikleri karşılaması gerekmektedir. Tablo 1' de hızlı büyüyen KOBI'lerin gelişim evreleri görülmektedir (Autio ve diğerleri, 2007: 20). Hızlı büyüyen işletme sürece "fırsatlarla karşılaşma" evresi ile başlar. Çoğu yeni işletme fikri, teknolojik fırsatların, girişimcinin yetenekleri ve güçlü taraflarının farkına varmasıyla ortaya çıkar (Autio ve diğerleri, 2007: 21). Bir iş fikrini başarıya dönüştürmek, yaratıcıllğı veya yenilikçiliği harmanlamayı gerektirdiği gibi bir işletmenin yaşam döngüsünün tüm aşamalarında gelişimini optimize etmek için uyarlama becerisini gerektirir. Umut vadeden bir iş fikri oluşturulduktan sonra "fırsat çerçevesini çizme" aşaması başlar. Bu aşamada, fırsatın fizibilitesine dair bir değerlendirme yapılır. Bu, tipik olarak tek bir birey veya ekip tarafından yürütülen bir süreçtir (Autio ve diğerleri, 2007: 21). Fizibilite deneyim, bilgi ve uzmanlık gerektiren bir proje faaliyetidir. Bir yatırımı mali, teknik yönleri ve sektörel/ekonomik boyutları ile ortaya koyan, fikir olarak var olan projeye yatırımın kabul veya red edilmesine yönelik analizleri de içeren bir çalışmadır. Fizibilite çalışmalarının yeterli bilgiye dayandırılarak yapılamaması, pazar seçimi, ürün seçimi, teknoloji, ölçek ve kuruluş yeri gibi konularda geriye dönülmesi çok zor stratejik hatalara neden olmaktadır (Atay, 2013).

Fırsatların çerçevesi çizildikten sonra "başlangıç öncesi" aşamasına geçilir. Bu aşama boyunca gerekli kaynakların belirlenmesi ve bu kaynaklara erişimin sağlanması gerekmektedir (Autio ve diğerleri, 2007: 20). Kuruluş aşamasında mevcut işletme sermayesi yeterli olmayan ve yabancı sermaye bulmakta sıkıntı yaşayan KOBİler, pazardaki ve genel ekonomik koşullardaki olumsuzluklardan etkilenmektedirler. Bu olumsuz koşulların varolması durumunda KOBİler, işletme sermayesi ihtiyacını karşılayamamaları durumunda ağır sonuçlara katlanmak zorunda kalmaktadırlar. Varolan üretim kapasitelerini artırma ve yenilenme için KOBI'lerin gerekli atılımlar yapma imkânları azalmaktadır (Hacievliyagil, 2016). KOBİ'lerin, bugün karşılaştı ğı birçok sorunun temelinde yatan asıl problem sermayedir. Girişimciler ayakta kalmak için gerekli olabilecek sermayeye sahip olmadan ellerinde bulunan küçük sermayeler ile işletmeler kurmakta ve bu var olan sermaye yatırım yapmakla birlikte yapılması şart olan ve işletmeyi geliştiren pazarlama faaliyetleri için yetersiz kalmaktadır. KOBI'ler piyasa şartlarından kaynaklı vadeli satışlarını da özsermayeleri ile karşılamak zorunda kalmaktadırlar. Daha işletmenin kuruluş aşamasında başlayan bu sermaye sıkıntısı KOBİ'leri işletme yaşam döngüsü boyunca olumsuz etkilemektedir. KOBİlerin bu özsermaye sıkıntısı gelişmiş teknolojileri edinmelerine engel olmakta ve eski teknolojilerle daha yoğun ve verimsiz çalışmak durumunda kalmaktadırlar. Bu da ürettikleri malın kalitesinin rekabet edilebilir olması gereken kalite standartlarında olmamasına neden olmaktadır. Kalitesiz üretim, KOBİlerin satış gücünü, dolayısıyla büyük işletmelerle rekabet gücünü azaltmaktadır. Eski teknolojilerle yapılan üretim ile ihracat yapılmasının ve uluslararası pazarlarda yer edinip rekabet etmenin imkânı yoktur (Uçkun, 2009). Bu yüzden bu aşamadaki politika; hızlı büyüyen işletme olabilmek için gerekli olan kaynakların var olduğundan emin olmaktır (Autio ve diğerleri, 2007: 20).

Son aşama olan piyasaya giriş aşamasında, yeni girişim, herhangi bir yeni işletmenin kaçınılmaz olarak geçmesi gereken alışılmış piyasa kabul testlerinden geçmektedir. Yenilikçi ve büyüme potansiyeli yüksek girişimlerin iş süreçleri pazardaki diğer girişimlerle benzerlik göstermekle birlikte bu işletmeler, yenilikçi 
M. Öztürk Dugan - N. Tosunoğlu 12/2 (2020) 2061-2079

süreçlerinin piyasada kabul görmesi için diğer işletmelerden daha fazla mücadele etmek zorunda kalabilirler (Autio ve diğerleri, 2007: 21).

Tablo 1. Hızlı Büyüyen KOBİ Gelişim Evreleri

\begin{tabular}{|c|c|c|c|c|}
\hline & \multicolumn{4}{|c|}{ Evreler } \\
\hline & $\begin{array}{l}\text { Firsatlarla } \\
\text { Karşılaşma }\end{array}$ & $\begin{array}{l}\text { Fırsatların } \\
\text { Çerçevesini Çizme }\end{array}$ & Başlangıç Öncesi & Piyasaya Giriş \\
\hline Seviye & Firsatları tanıma & Girişimsel taahhütler & $\begin{array}{l}\text { Başlangıç } \\
\text { platformu }\end{array}$ & Meşruiyet \\
\hline $\begin{array}{l}\text { Seviyeye } \\
\text { erişime } \\
\text { katkıda } \\
\text { bulunan kritik } \\
\text { faktörler }\end{array}$ & $\begin{array}{l}\text {-Piyasa bilgisi } \\
\text {-Müşteri ihtiyaçları } \\
\text { bilgisi } \\
\text {-Piyasaya erişimin } \\
\text { yolunun çizilmesi } \\
\text {-Ticari ve } \\
\text { girişimsel dürtüler } \\
\text {-Girişimcilik } \\
\text { seçeneklerine } \\
\text { duyarlılık }\end{array}$ & $\begin{array}{l}\text {-Firsatların } \\
\text { boyutunun tahmini } \\
\text {-Kaynak } \\
\text { gereksinimlerinin } \\
\text { belirlenmesi } \\
\text {-Yaşamsal etkilerin } \\
\text { tespiti } \\
\text {-Uygulanabilir iş } \\
\text { modellerinin } \\
\text { belirlenmesi }\end{array}$ & $\begin{array}{l}\text {-İş planlaması, } \\
\text { kaynakların } \\
\text { mobilize edilmesi } \\
\text {-Arz zinciri ve } \\
\text { müşteriler } \\
\text { tarafından ön } \\
\text { kabul }\end{array}$ & $\begin{array}{l}\text {-̇̇şletmenin hayata } \\
\text { geçmesi } \\
\text {-̧̇̇ iliş̧kilerinin tesisi } \\
\text {-̇̇ş modellerinin test } \\
\text { edilmesi } \\
\text {-Yönetsel ve finansal } \\
\text { standartların } \\
\text { belirlenmesi } \\
\text {-̇̇vme yaratma }\end{array}$ \\
\hline $\begin{array}{l}\text { Politika } \\
\text { uygulamaları }\end{array}$ & $\begin{array}{l}\text {-Fırsatları } \\
\text { belirleme } \\
\text { kabiliyetinin } \\
\text { kazandırılması } \\
\text {-Girişimsel } \\
\text { yeteneklere sahip } \\
\text { nufusun } \\
\text { arttırılması } \\
\text {-Girişimcilik } \\
\text { kariyer } \\
\text { seçeneklerinin } \\
\text { geliştirilmesi }\end{array}$ & $\begin{array}{l}\text {-Firsatları } \\
\text { değerlendirme } \\
\text { yeteklerinin } \\
\text { geliştirilmesi } \\
\text {-Girişimcilik kariyer } \\
\text { bedellerinin } \\
\text { azaltılması } \\
\text {-Kaynakların ve } \\
\text { hizmetlerin elde } \\
\text { edilebilir hale } \\
\text { getirilmesi }\end{array}$ & $\begin{array}{l}\text {-Kaynaklara ve } \\
\text { çekirdek } \\
\text { finansmanına } \\
\text { erişimin } \\
\text { kolaylaştırılması } \\
\text {-İş altyapısının ve } \\
\text { koçluk } \\
\text { hizmetlerinin } \\
\text { sunulması } \\
\text {-Sosyal } \\
\text { sermayenin ve } \\
\text { networklerin } \\
\text { sunulması } \\
\text {-Küçük ve büyük } \\
\text { işletmelerin } \\
\text { iliş̧kilerinin } \\
\text { geliştirilmesi } \\
\text {-Piyasaya girişin } \\
\text { kolaylaştırılması }\end{array}$ & $\begin{array}{l}\text { - Uyum maliyetinin } \\
\text { düşürülmesi } \\
\text { - Düzenleyici } \\
\text { çerçevenin } \\
\text { sinırlarının } \\
\text { belirlenmesi } \\
\text { - Danışmanlık } \\
\text { hizmetlerinin } \\
\text { sunulması }\end{array}$ \\
\hline
\end{tabular}

Kaynak: Autio ve diğerleri, 2007

\subsection{Hızlı Büyüme Aşamaları}

Bir fikirden başarılı bir yüksek büyüme organizasyonuna giden yolda pek çok aşama mevcuttur. Bu aşamalar Tablo 2'de verildiği gibi basit bir şekilde özetlenebilir (Autio ve diğerleri, 2007: 23). 
M. Öztürk Dugan - N. Tosunoğlu 12/2 (2020) 2061-2079

Tablo 2. Yenilikçilik Odaklı Bir Büyüme Aşamasının Şematik Gösterimi

\begin{tabular}{|c|c|c|c|c|}
\hline & Erken Aşama & Genişleme & Olgunluk & Çeşitlendirme \\
\hline $\begin{array}{l}\text { Temel Büyüme } \\
\text { Faktörleri }\end{array}$ & $\begin{array}{l}\text {-ArGe } \\
\text {-Ticarileştirme } \\
\text {-Kaynak elde etme }\end{array}$ & $\begin{array}{l}\text {-Satış ve pazarlama } \\
\text {-Üretim } \\
\text {-Kaynak elde etme }\end{array}$ & $\begin{array}{l}\text {-Yönetsel Kapasite } \\
\text {-İçsel kontrol }\end{array}$ & $\begin{array}{l}\text {-Yeni pazarlar } \\
\text { belirleme }\end{array}$ \\
\hline $\begin{array}{l}\text { Yapisal } \\
\text { Karakteristikler }\end{array}$ & $\begin{array}{l}\text {-Basit organizasyon } \\
\text {-Düşük } \\
\text { formalizasyon } \\
\text {-Düşük uzmanlaşma } \\
\text {-Yüksek } \\
\text { merkezileşme }\end{array}$ & $\begin{array}{l}\text {-Amaçsal } \\
\text { organizasyon } \\
\text {-Gelişen } \\
\text { formalizasyon } \\
\text {-Orta düzey } \\
\text { uzmanlaşma } \\
\text {-Yüksek } \\
\text { merkezileşme }\end{array}$ & $\begin{array}{l}\text {-Amaçsal } \\
\text { organizasyon } \\
\text {-Düşük } \\
\text { formalizasyon } \\
\text {-Yüksek uzmanlaşma } \\
\text {-Yüksek } \\
\text { merkezileşme }\end{array}$ & $\begin{array}{l}\text {-Bölümsel } \\
\text { organizasyon } \\
\text {-Yüksek } \\
\text { formalizasyon } \\
\text {-Yüksek uzmanlaşma } \\
\text {-Düşük merkezileşme }\end{array}$ \\
\hline $\begin{array}{l}\text { Girişimci } \\
\text { Davranışları }\end{array}$ & $\begin{array}{l}\text {-Fırsatların farkına } \\
\text { varma } \\
\text {-Fırsatların } \\
\text { çerçevesini çizme }\end{array}$ & $\begin{array}{l}\text {-Fırsatların } \\
\text { çerçevesini çizme } \\
\text {-Fırsatları takip etme }\end{array}$ & $\begin{array}{l}\text {-Firsatları takip etme } \\
\text {-İş konsolidasyonu }\end{array}$ & $\begin{array}{l}\text {-İş konsolidasyonu } \\
\text {-Stratejik Kaldıraç } \\
\text {-Fırsatların farkına } \\
\text { varma }\end{array}$ \\
\hline
\end{tabular}

Kaynak: Autio ve diğerleri, 2007

Erken aşamada fırsatlara dikkat etme, girişimcilik motivasyonu ile birlikte kritik girişimci davranışları olmakla birlikte sınırlı düzeyde bir yönetsel yetenek ihtiyacı ortaya çıkmaktadır (Autio ve diğerleri, 2007: 22). $\mathrm{Bu}$ aşamadaki temel büyüme faktörleri, Ar-Ge, ticarileştirme ve kaynak elde etmedir. Erken aşamada girişimci işletmeler fırsatları belirler, bunlardan yararlanmaya karar verir ve bunu yapmak için gerekli kaynakları arar. Büyüme önemli finansal kaynaklar gerektirir. Araştırmalar hızlı büyüme gösteren işletmelerin hızlı büyüme gösteremeyen işletmelere kıyasla daha yüksek bir finansal kaynağa sahip olduğunu göstermiştir (Moreno ve Casillas, 2007).

Genişleme aşamasında girişimcinin motivasyonu ve yöneticilik becerilerinin önemi artarken fırsatlara duyarlılığın önemi erken aşamaya göre azalmaktadır. Bu aşamadaki temel büyüme faktörleri, satışpazarlama, üretim ile birlikte kaynak elde etme önem göstermektedir. Hızlı büyüyen KOBI'ler pazar odaklıdırlar, diğer işletmelerle ilişkilerini geliştirir ve sıkı tutarlar. Müşteriyi pazarlama faaliyetlerinin odağına koyarak pazarlama karmalarını oluştururlar. Müşterinin taleplerine karşılık verilerek memnuniyetinin sağlanması ve sürekli daha kaliteli ürün sunma amacı, gelir arttırmaktan daha önce gelir. Hızlı büyüyen KOBİler ürün farklılaştırmayı rakiplerine kıyasla daha iyi organize edebildiklerinden var olan pazarlarını sürekli olarak genişletirler. Pazarın büyümesi ile birlikte daha fazla müşteri ile muhatap olunmaya başlanır bu sebeple müşteri odaklılık bu işletmeler için en öncelikli konudur (Güzel ve Giray, 2014).

Olgunluk aşaması girişimci açısından fırsatlara duyarlılık, girişimcinin motivasyonu ve yöneticilik becerilerinin daha durağan olduğu bir dönemi göstermektedir. Tablo 2' de görüldüğü gibi bu aşamadaki temel büyüme faktörleri yönetsel kapasite ve içsel kontroldür. Bu safhada işletme verimlilik ve etkinlik üzerine yoğunlaşmaktadır. Verimlilik, üretimde uygulanan kaynakların kullanımında atıl kaynakların azaltılması anlamına gelir. Ekonomik açıdan bakıldığında, belirli bir girdi kümesinden elde edilen çıktı miktarıdır. Girişimciliğin bir ekonominin üretkenliği üzerinde istikrarlı ve önemli bir etkiye sahip olduğu bilinmektedir. Spesifik olarak, hızlı büyüyen işletmelerde verimlilik ve yüksek büyüme arasında bir döngü olduğuna dair kanıtlar vardır. Üretkenliği yüksek olan işletmelerin satışlarda daha hızlı büyümesi muhtemel, hızlı büyüyen işletmelerin yüksek verimliliğe ulaşması diğerlerine göre daha olasıdır (Monteiro, 2019).

Çeşitlendirme aşamasında ise girişimci açısından fırsatlara duyarlılık ve girişimcinin motivasyonu durağan seyrederken, yöneticilik becerilerinin öne çıktığı bir dönem yaşanmaktadır. Bu aşamadaki temel büyüme faktörü, yeni pazarlar bulmaktır. Başarılı bir büyümeden sonra işletmenin konumunu sağlamlaştırması ve kademeli olarak, belki de ilgili ürünlerinde çeşitlendirme ve yeniden genişleme fırsatları aramaya başlaması gerekir. Bu aşama artık girişimcilik politikalarının kapsamı dışında kalmaya başlar ve endüstrideki politikalar daha etkin olur (Autio ve diğerleri, 2007: 13). 


\section{M. Öztürk Dugan - N. Tosunoğlu 12/2 (2020) 2061-2079}

\section{3. İÇ GİRIŞIMCİLIKK}

İç girişimcilik, girişimsel düşünce sonucunda oluşan ve yenilikçi düşünce tarzı, beceri ve kapasite elde etme kabiliyetini artırmaya odaklanan bir kavramdır. Bu kazanımı elde edebilen örgütler, rakiplerinden bir adım daha önde olma şansını yakalayabilmektedir. Yoğun rekabetin hâkim olduğu, belirsiz ve karmaşık pazar koşullarının geçerli olduğu bir ortamda, sürdürülebilir rekabet avantajı elde etmenin yolu, yenilik yapmaktan geçmektedir. Bir örgütü yenilik yapmaya teşvik eden güç ise, iç girişimciliktir (Fiş ve Çetindamar, 2007; akt Gürel, 2012). Girişimcilik kavramı bir örgüt içerisinde, örgütsel kârlıllğgl ve örgütün rekabet gücünü yükseltmek ve stratejik yenilenmeyi gerçekleştirebilmek için yeni iş yaratma sürecini ifade etmektedir (Gürel, 2012). Schumpeter, büyük işletmelerin ortaya çıkması ile birlikte girişimciliğin iktisadi sistem içerisindeki rolü ve etkisinin azalacağını ileri sürmüş ve iç girişimciler adı verilen işletme içi yenilikçi ekipler tarafından yeniliklerin gerçekleştirileceğini ifade etmiştir (Eyel ve diğerleri, 2019). Girişimcilik işletme dışındaki girişimcilik çabalarını tanımlamakta ve yeni organizasyonlar yaratma anlamında iken iç girişimcilik hâlihazırda faaliyette olan işletme içerisindeki girişimsel çabaları ifade etmektedir. Buradan iki kavram arasındaki en temel farkın faaliyetin gerçekleştiği yer olduğu görülmektedir (Ağca ve Yörük, 2006: 165). İç girişimci sözcüğü ilk kez Pinchot (1985) tarafından kullanılmıştır. Pinchot iç girişimciyi herhangi bir iş fikrini uygulama sorumluluğunu bulunduğu işletmede üstlenen birey olarak ifade etmektedir. Her işletme kârlı büyüyerek ömrüne devam etmek için yeni fikirlere ihtiyaç duyacağından sistemdeki girişimsel yenilikçilik sürecini icra edecek iç girişimcilere ihtiyaç duyarlar (Seshadri ve Tripathy, 2006).

İç girişimcilik bir işletmenin içinde girişimciliğe ortam sağlayan yapıdır. İç girişimciler meslektaşları onların hevesini kırsa bilse muhteşem fikirleri olan ve onları gerçekleştirme isteğine sahip olan kişilerdir. İç girişimciliğin işletmeye kattığı en büyük değer, işletmenin varlığını daha sürdürebilir bir şekilde uzun yıllara taşımasıdır. İç girişimci, işletmesinin daha kârlı ve rekabetçi bir yapıda olmasında önemli bir rol oynar. Popüler bir örnekle iç girişimcilik açıklanacak olursa; Ken Kutaragi (Sony Yönetim Kurulu Eski Başkanı), işletmenin ses laboratuvarlarında çalışırken kızına aldığı Nintendo oyun konsolunu geliştirebileceğini düşünür ve bir süre Nintendo işletmesiyle de çalışır. Bu durum Sony tarafından fark edilir ve Kutaragi, işletmeden kovulma noktasına gelir. Zamanın CEO'su Norio Ohga onun yenilikçi bakış açısını değerlendirir ve işletmede tutarak ondan maksimum verimi almaya karar verir. Kutaragi daha sonra şu an Sony'nin en güçlü alanlarından olan oyun konsolu sektöründeki silahı PlayStation'un kurucularından olacaktır (Gershon ve Kanayama, 2002). Ülkemizde ise Arçelik, Vestel vb. işletmelerin yanında uluslararası arenada IBM, Lockheed Martin, 3M ve Google gibi işletmeler iç girişimciliği farklı formlarda işletmelerinde yürütmektedirler (Yener, 2019).

Örgütsel ve ekonomik gelişmede önemli bir unsur olan iç girişimcilik, özellikle işletmelerin performansı üzerine olumlu etkilerinden dolayı 1980'den bu yana hem akademik alanda hem de uygulayıcı işletmelerde yoğun ilgi gören bir kavram haline gelmiştir (Antoncic ve Hisrich, 2003).

\section{1. İ̧̧ Girişimciliğin Boyutları}

İç girişimcilik olgusu her işletmede farklı düzeylerde olsa da tüm örgütlerde bulunmaktadır. Temel sorun iç girişimciliğin ne düzeyde olduğunun belirlenebilmesi, dolayısıla ölçülebilmesi sorunudur. Bu sorunun çözümlenebilmesinde iç girişimciliğin boyutları yardımcı olmaktadır (Ağca ve Kurt, 2007). Literatür incelediğinde karşılaşılan yedi iç girişimcilik boyutu aşağıda açıklanmıştır.

i. Yenilikçilik (innovation), araştırmacılar ve uygulayıcılar tarafından çeşitli şekillerde tanımlanmaktadır. Bazıları bu kavrama "değer" yönüyle bakmış; bazıları ise, "yenilik" (newness) veya "orijinallik" (novelty) derecesine dayanarak kavramı açıklamaya çalışmıştır. Yenilikçilik, bir işletmeye ekonomik değer katarak karlılığı veya diğer performans kriterlerini etkilediği zaman değerlidir (Gülbahar, 2019).

ii. Risk, zarar ya da kayıplara yol açabilen istenmeyen olayların ortaya çıkma olasılığı demektir. İşletmelerdeki girişimcilik faaliyetlerinin bütün organizasyonel süreçleri risk ve risk alma etkileriyle oluşmaktadır. Girişimcilik bakımından yeni ürünlerin yaratılması, yeni süreçlerin kullanılması, yeni pazarlara girilmesi gibi faaliyetlerin hepsi birçok risk içermektedir. Bu bakımdan girişimsel riskler; yeni girişimler, kuruluşlar, ürünler ya da süreçler ile ilgili belirsizlikler ve riskler altında verilen kararlar biçiminde görülebilmektedir (Arslanoğlu, 2018). 
iii. Proaktiflik, gelecekte ortaya çıkacak sorunlardan, ihtiyaçlardan ve değişimlerden önce harekete geçme olarak tanımlanmaktadır (Yılmaz ve Bakan, 2019). İç girişimcilerin hızlı bir şekilde değişen çevre koşullarına ayak uydurabilmek ve bir adım öne geçebilmek amacıyla çevrenin gelecekteki isteklerini tahminleyerek potansiyel taleplere rakiplerden önce cevap verebilecek yapıda öncü olması proaktiflik olarak ifade edilmiştir. İç girişimciliğin özünde fırsatları değerlendirmek için harekete geçme dürtüsü vardır. Bu açıdan proaktiflik, örgütlerin pazarda lider olma girişimlerinde, rakiplere göre temel faaliyet alanlarında ürün ve hizmetleri, teknolojileri yönetim tekniklerini daha önceden sunmasıyla ilgilidir (İçerli ve diğerleri, 2011).

iv. Özerklik, çalışanların düşünce ve vizyonlarını net ve açık bir şekilde ifade etme ve bağımsız bir şekilde hareket etme yetkinliği olarak tanımlanmaktadır. İşletmelerde girişimcilik ve yaratıcllı̆ın gelişmesinde kişi ve takımlara sağlanan özgürlük önemli bir unsurdur. Özerklik, bir fikir ya da vizyonu ortaya koyma veya tamamlama dönemlerinde bağımsız olarak hareket etme eylemi olup, fırsat arayışında kendini bağımsız olarak yönetme yeteneği ve iradesidir (Lumpkin ve Dess, 1996; akt. Yılmaz ve Bakan, 2019).

v. Yeni iş girişimlerini başlatma, hali hazırda var olan örgütlerde yeni bir iş kurma, işletmenin ürünlerinin veya hizmetlerinin yeniden adlandırması, çeşitlendirilmesi ya da yeni pazarlara girişidir (Antoncic ve Hisrich, 2001). İç girişimciliğin sürekli olarak işletmeler için yenilikler geliştirmesi ile ortaya çıkan çıktıları satışa dönüştürme çabası, yeni bir girişimin başlangıcını ifade etmektedir. Var olan bir faaliyetin geliştirilmesi, yeni bir şeylerin ortaya konması ve farklı ürünlerin tasarlanması yeni iş girişimi sürecinin içerisindedir (Hevesli, 2016).

vi. Kendini yenileme (Stratejik yenilenme) boyutu organizasyonların dönüşümünü ve bu süreçte örgütsel değişimin önemi ve gerekliliğine vurgu yapmaktadır. Stratejilerin yeniden oluşturulması, örgütsel değişim ve yeniden tanımlamak, misyonu sık sık gözden geçirmek, yenilikçilik ve yaratıcılık için eğitime önem vererek bu süreçleri geçirmeyi gerekli kılar. Bu nedenle, diğer faktörlerden ziyade, stratejik yenilenme boyutu dinamik yapısından dolayı farklı bir yere sahiptir (Güney, 2015: 331).

vii. Rekabetçi girişkenlik, rakiplere karşı üstün gelme isteğini ifade etmektedir. Bu faktör rakiplerden gelen tehditlere karşıllk bir tutumdur. İç girişimcilik faaliyetleri sonucunda işletmeler rakip işletmelerin faaliyet gösterdiği alanlara ve pazarlara girebilmektedir. Rakiplerin zayıf yanlarının teşhis edilmesi ve bunlara yoğunlaşarak politikalar oluşturmak, iç girişimcilik faaliyetlerinin önemli bir boyutudur. Bu faktör bazen proaktiflik ile karıştıılmaktadır. Proaktiflik pazardaki fırsatları değerlendirmek konusunda öncü olmayı ifade ederken, rekabetçi girişimciliğin pazardaki tehditleri gidermeye yöneliktir (Kozak ve Yılmaz, 2010: 90).

\section{2. İ̧̧ Girişimciliği Etkileyen Faktörler}

Literatürde iç girişimciliği etkileyen faktörler; örgütsel faktörler ve çevresel faktörler olmak üzere iki temel grupta ele alınmıştır. Örgütsel ve çevresel faktörlerin iç girişimciliğe yönelik olumlu etkisi ve buna bağlı olarak iç girişimciliğin de işletme performansını belirleyen büyüme ve kârlılık üzerine olumlu etkisi olduğu ifade edilmiştir (Şekil 2) (Uzun, 2018). 


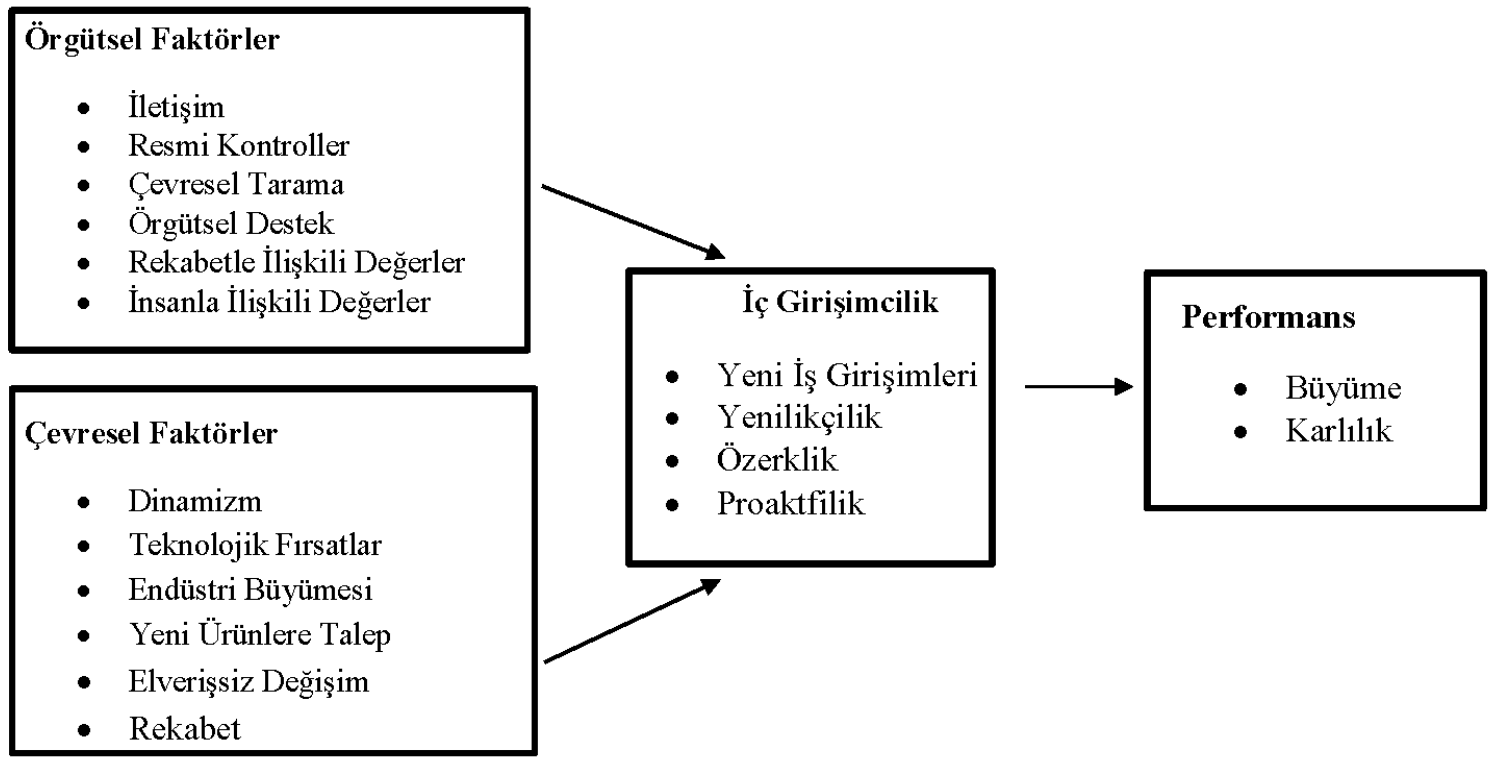

Şekil 2. İç Girişimcilik Modeli ve Doğrudan Etkileri

Kaynak: Uzun, 2018

İç girişimciliği etkileyen örgütsel faktörler

i. İletişim kanallarının açı olması; kişilere yönetimin beklentilerini, işleri nasıl yapmaları gerektiğini öğreten bir kavramdır. Bununla birlikte kişiler, üst amirlerinin ve iş arkadaşlarının kendileri hakkındaki düşüncelerini öğrenme fırsatına erişirler (Bozkurt ve Bozkurt, 2008).

ii. Kontrol mekanizmalarımın varlı̆̆l; var olan iş süreçlerinin gözden geçirilmesi ve çalışanların yeteneklerinin gelişimi için işletmelerde ihtiyaç duyulan bir kavramdır. İşletmelerdeki iç girişimcilik faaliyetlerini gözlemlemek için resmi kontrollerin olması, girişimciliğin pozitif bir uyaranı olarak görülmektedir.

iii. Çevreyi tarama sıklı̆gl; iç girişimciliğe verilen değer ile ilgilidir. Çevrede fark edilen bir fırsat iç girişimciliğin başlangıcını tetikleyen noktadır (Naktiyok ve Kök, 2006; Onay ve Çavuşoğlu, 2010).

iv. Yönetim anlamında destek; uzun vadede işletmenin sürdürülebilirliğini sağlamak ve rekabet üstünlügünü koruyabilmek için gereklidir. Yöneticiler yenilikçi fikirleri dinleyip değerlendirmeli ve projeleri desteklemeye yönelik bir felsefe oluşturmalıdırlar (Bulut ve diğerleri, 2008).

v. Örgütsel değerler; bireylerin sürekli olarak yeni fikirler, bilgiler ve çözümler üretmeleri için teşvik oluşturması sebebiyle iç girişimciliğin önemli bir parçasıdır (Antoncic, 2007).

vi. Ödül sisteminin varlığl; iç girişimci bireyleri teşvik edecektir. Girişimsel faaliyetlerin örgüt içerisinde yaygınlaşması için iç girişimcilere karar verme ve sorumluluk hakkı verilmeli, yeni fikirler üretebilmeleri için ödüllendirilme yapılmalıdır (Onay ve Çavuşoğlu, 2010).

İ̧ girişimciliği etkileyen çevresel faktörler

i. Çevresel dinamizm; kuruluşun çevresinde hem değişim oranını hem de tahmin edilemezliğini ifade eder; kararlar ile yüksek dinamik arasında değişen bir ölçüttür. Dinamizm, işletmenin pazarda fırsat yaratmasına sebep olduğu için iç girişimcilik ile olumlu bir ilişkisi vardır (Heavey ve diğerleri, 2009).

ii. Teknolojik firsatlar; örgütlerin, üretime yönelik yapmış oldukları değişimi ifade etmektedir. Tedarikçilerin, müşterilerin isteklerine zamanında yanıt verilebilmesi için yapılan yazılım, donanım ve makina yatırımlarıdır (Günay, 2018).

iii. Sektörel büyüme; büyüyen endüstriler işletmelere iç girişimcilik faaliyetlerini artıracak fırsatlar sağlar. Sektördeki büyümeye yönelik fırsatların varlığı-çokluğu-azlığı, sektörün büyümesine yönelik çekici fırsatlar sunup sunmadığı işletmelerin iç girişimcilik faaliyetleriyle pozitif olarak ilişkilidir. 
iv. Yeni ürünlere talep; yeni ürünlere olan talep iç girişimciliği özendiren ve cesaretlendiren önemli bir pazar cazibesidir. Yeni ürünlere olan talep, işletmenin yatırımlarınının yönünü tayin eder, yeni ürün geliştirmeye ve bu ürünleri pazara sunmaya zorlar (Durmaz, 2011).

v. Çevredeki elverişsiz radikal değişiklikler; olumsuzluk olarak nitelendirilir. Çevrede meydana gelen devam eden değişikliklerin işletme amaç ve misyonuyla örtüşmememesinin algılanmasıdır (Durmaz, 2011).

vi. Yoğun rekabet; pazardaki rekabetin yoğunluğunu tanımlayan bir faktördür. Rakiplerin sayısı, izledikleri stratejiler, kullanılan teknoloji gibi değişkenler bu faktörü etkiler. Yoğun rekabet işletmelerin yenilikçiliğe yönelebilmesi için itici güçtür (Ağca, 2005).

\section{YÖNTEM}

Bu bölümde hızlı büyüyen KOBİ'lerin iç girişimcilik düzeylerinin belirlenmesi ve hızlı büyümeyen KOBİlerle farklılı̆̆ının incelenmesi amacıyla yapılan araştırmaya yer verilmiştir.

\subsection{Araştırma Deseni ve Araştırma Hipotezleri}

Bu çalışma, hızlı büyüyen KOBİ'lerin iç girişimcilik düzeylerinin diğer KOBİ'lerden farklı olduğunu belirlemek amacıyla gerçekleştirilen karşılaştırmalı nicel bir araştırmadır.

Çalışmanın araştırma hipotezleri iç girişimciliğin alt boyutlarına dayanarak aşağıdaki gibi kurulmuştur:

H1: Hızlı büyüyen ve hızlı büyümeyen KOBİlerin yenilikçilik düzeyleri farklılık göstermektedir.

H2: Hızlı büyüyen ve hızlı büyümeyen KOBI’lerin yeni girişim düzeyleri farklılık göstermektedir.

H3: Hızlı büyüyen ve hızlı büyümeyen KOBİ'lerin örgütsel yenilenme düzeyleri farklılık göstermektedir.

H4: Hızlı büyüyen ve hızlı büyümeyen KOBI’lerin proaktif davranış düzeyleri farklılık göstermektedir.

\subsection{Evren ve Örneklem}

Çalışmanın evreni Ankara ilinde faaliyette bulunan KOSGEB veri tabanına kayıtlı işletmelerdir. Toplam işletme sayısının yaklaşık 65.233 olduğu tespit edilmiştir (2019 yılı). Evrendeki birim sayısı zaman ve maliyet kısıtları sebebiyle ulaşılamayacak büyüklükte olduğundan çalışmada örneklemeye gidilmiştir. Örneklemde yer alacak birim sayısının belirlenmesinde, anlamlılık seviyesi 0,05 ve hata payı $\pm 0,05$ seçilmiştir. Araştırma konusu ile ilgili daha önceden herhangi bir araştırma yapılmadığından bir birimin örnekleme seçilme olasılığını ifade eden p değeri 0,5 olarak alınmıştır. Yazıcıoğlu ve Erdoğan (2004)'ın çalışmalarında yer alan “ $\alpha=0.05$ İçin Örneklem Büyüklükleri" tablosundan yararlanarak örneklemde yer alacak işletme sayısının en az 383 olması gerektiği bulunmuştur. Basit tesadüfi örnekleme yöntemi kullanılarak minimum sayıya ulaşılmaya çalşılmış, yapılan değerlendirmeler sonucunda kullanılan birim sayısı toplam 429 olmuş ve istatistiksel analizlerin yapılabilmesi için gerekli sayı sağlanmıştır.

\subsection{Verilerin Toplanması}

Araştırma verilerinin toplanmasında anket tekniğinden yararlanılmıştır. Anketler katılımcılara, KOSGEB Strateji Geliştirme Daire Başkanlığı onayı ile KOSGEB veri tabanına kayıtlı Ankara ilinde faaliyette bulunan işletmelere e-posta ile iletilmiştir. Anket iki bölümden oluşmaktadır. Birinci bölümde işletmlerin hızlı büyüyüp büyümediklerini tespit etmeye yönelik genel işletme bilgileri sorulmuştur. İkinci bölümde, karar verme yetkisine sahip, işletme yöneticilerinin, her departmandan müdür ve müdür yardımcılarının iç girişimcilik düzeyini ölçmeye yönelik Naktiyok'un (2004) geliştirdiği “İç Girişimcilik Ölçeği” kullanılmıştır. Söz konusu ölçek kapsamında 4 boyutta ifade edilen 18 madde yer almaktadır. Bu boyutlar; yenilikçilik, yeni girişim, örgütsel yenilenme ve proaktif davranıştır. Ölçek 5'li Likert tipinde düzenlenmiştir. Katılımcılara “Aşağıdaki her ifadeye ne derece katıldığınızı aşağıda verilen 'Çok Önemsiz (1)' seçeneğinden, 'Çok Önemli (5)' seçeneğine doğru giden ölçeği kullanarak işaretleyiniz." sorusu yöneltilmiştir.

Araştırmaya toplam 601 işletme katılmıştır. Çalışmanın amacı doğrultusunda kuruluş tarihi 2017 yılı ve sonrasında olan işletmeler ile mevcut durumlarında beş eleman sayısının altında istihdam sağlayan işletmeler analize alınmamıştır. Buna göre 429 işletme analize dahil edilmiştir. 429 işletmenin hızlı büyümelerinin değerlendirilmesinde, anketin birinci bölümünde yer alan bilgilere dayanarak, 2016-2017-2018 yıllarında yıllık ortalama çalışan sayısında veya işletme satışlarında \%20 artış sağlamış olmaları dikkate alınmıştır. Buna göre 
M. Öztürk Dugan - N. Tosunoğlu 12/2 (2020) 2061-2079

hızlı büyüme sağladıkları tespit edilen 261 işletme olduğu gözlenmiş, geriye kalan 168 işletme ise hızlı büyümeyen işletme olarak belirlenmiştir.

\subsection{Geçerlik ve Güvenirlik Analizleri}

İç girişimcilik için uygulanan ölçeğin yapı geçerliliğinin sağlanmasında faktör analizinden yararlanılmıştır. Güvenirlik için ise Cronbach- $\alpha$ katsayıları hesaplanmıştır. Sonuçlar Tablo 3' de verilmiştir.

Tablo 3. İç Girişimciliğe İlişkin Faktör Analizi Sonuçları

\begin{tabular}{|c|c|c|c|c|}
\hline Maddeler & Yenilikçilik & $\begin{array}{c}\text { Yeni } \\
\text { Girişim } \\
\end{array}$ & $\begin{array}{c}\text { Örgütsel } \\
\text { Yenilenme }\end{array}$ & $\begin{array}{c}\text { Proaktif } \\
\text { Davranış }\end{array}$ \\
\hline 1.Ürünleri/Sistemlerifarklılaştırmak & 768 & & & \\
\hline 2.Yenilikte ilk olmak & 819 & & & \\
\hline 3.Yenilik için kaynak ayırmak & 787 & & & \\
\hline 4.Yeni İ.K. programları uygulamak &, 591 & & & \\
\hline 5.Yeni yöntemleri kullanmak & ,616 & & & \\
\hline 7.İş kollarını genişletmek & & ,715 & & \\
\hline 8.Diğer endüstrilerden yeni işler almak & & ,788 & & \\
\hline 9.Yeni ürünle yeni pazara girmek & &, 578 & & \\
\hline 10.Yeni iş/işletme fırsatı aramak & & ,763 & & \\
\hline 11.Misyonu sık sık gözden geçirmek & & & ,724 & \\
\hline 12.Endüstrileri yeniden tanımlamak & & & 699 & \\
\hline 13.Bölümleri yeniden organize etmek & & & ,770 & \\
\hline 14.Çalışanları yenilik için eğitmek & & & ,497 & \\
\hline 15.Rakiplerlerle mücadele etmek & & & & 458 \\
\hline 16.Risk taşıyan projeleri uygulamak & & & & ,823 \\
\hline 17.Stratejik faaliyetleri tercih etmek & & & & 673 \\
\hline 18.Cesur davranarak karar almak & & & & 643 \\
\hline Faktör Güvenirlikleri (Cronbach- $\alpha$ ) & $\alpha=0,876$ & $\alpha=0,834$ & $\alpha=0,864$ & $\alpha=0,782$ \\
\hline Varyans Açıklama \% & 21,067 & 16,650 & 16,610 & 14,108 \\
\hline \multicolumn{5}{|c|}{$\begin{array}{l}\text { Varimax Rotasyonlu Temel Bileşenler Analizi } \\
\text { KMO:0,941; Bartlett Küresellik Testi Ki-kare: 4204,195; sd: 136; Anl. Değeri: 0,000, p<0,05, Faktör analizi yapılabilir } \\
\text { Toplam Varyans Açılama Yüzdesi:\% 68,434 }\end{array}$} \\
\hline
\end{tabular}

Yapılan faktör analizi sonucunda 6. madde "Ürünler için yeni talep yaratmak" ifadesinin literatürdeki gibi yenilikçilik boyutunda yer almadığı görülmüştür. Bu durumda 6 . madde çıkarılarak faktör analizi yeniden yapılmış ve tüm alt boyutların doğrulandığı görülmüştür. Dört faktörün varyans açıklama yüzdesi \%68,434 olarak hesaplanmıştır. Cronbach- $\alpha$ katsayıları yenilikçilik boyutunda 0,876 , yeni girişim alt boyutunda 0,834 , örgütsel yenilenme alt boyutunda 0,864 ve proaktif davranış alt boyutunda 0,782 bulunmuştur. Ölçek güvenilir olarak değerlendirilmiştir.

\subsection{Verilerin Analizi}

Araştırma hipotezlerinin değerlendirilmesinde parametrik test koşullarının sağlanması koşuluyla iki grup ortalama farkının analizinde bağımsız gruplar için t-testi kullanılmıştır. Analizler SPSS.21 paket programı yardımıyla yapılmıştır.

\subsection{Bulgular}

Araştırmaya katılan işletmelere ilişkin demografik özellikler Tablo $4^{\prime}$ te verilmiştir. Hızlı büyüyen KOBİlerin $\% 89,3^{\prime}$ ü ile hızlı büyümeyen KOBI'lerin \%86,9'u ürün/mal sektöründe faaliyet göstermektedir. Kuruluş yılı en fazla \%58,6 ve \%47 ile 2006-2015 yılı aralığındadır. Faaliyete başlama çalışan sayısı en fazla \%94,6 ve \%92,3 ile 1-9 aralığındadır. KOBI'lerden hızlı büyüyenlerin \%27,2'si ihracatçı, \%45,6'sı imalatçı, iken hızlı büyümeyenlerin \%13,7'sinin ihracatçı, \%38,1'inin imalatçı olduğu söylenebilir. 
M. Öztürk Dugan - N. Tosunoğlu 12/2 (2020) 2061-2079

Tablo 4. Hızlı Büyüyen ve Hızlı Büyümeyen KOBİ’lerin Demografik Özellikleri

\begin{tabular}{|c|c|c|c|c|}
\hline & \multicolumn{2}{|c|}{$\begin{array}{l}\text { Hizlı Büyüyen } \\
\text { KOBİ }\end{array}$} & \multicolumn{2}{|c|}{$\begin{array}{c}\text { Hizlı Büyümeyen } \\
\text { KOBİ }\end{array}$} \\
\hline & $f$ & $\%$ of & $f$ & $\%$ f \\
\hline \multicolumn{5}{|l|}{ Faaliyet } \\
\hline Ürün/Hizmet & 28 & 10,7 & 22 & 13,1 \\
\hline Ürün/Mal & 233 & 89,3 & 146 & 86,9 \\
\hline \multicolumn{5}{|l|}{ Kuruluş Yılı } \\
\hline 1945 ile 1965 arası & 3 & 1,1 & 3 & 1,8 \\
\hline 1966 ile 1985 arası & 6 & 2,3 & 9 & 5,4 \\
\hline 1986 ile 2005 arası & 73 & 28,0 & 65 & 38,7 \\
\hline 2006 ile 2015 arası & 153 & 58,6 & 79 & 47,0 \\
\hline 2016 & 26 & 10,0 & 12 & 7,1 \\
\hline \multicolumn{5}{|c|}{ Faaliyete Başladığı Çalışan Sayısı } \\
\hline 1 ile 9 arası & 247 & 94,6 & 155 & 92,3 \\
\hline 10 ile 49 arası & 13 & 5,0 & 13 & 7,7 \\
\hline 50 ile 249 arası & 1 & 0,4 & 0 & 0 \\
\hline \multicolumn{5}{|l|}{ İhracat } \\
\hline İhracat yapıyor & 71 & 27,2 & 23 & 13,7 \\
\hline İhracat yapmiyor & 190 & 72,8 & 145 & 86,31 \\
\hline \multicolumn{5}{|l|}{ İmalat } \\
\hline İmalat yapıyor & 119 & 45,6 & 64 & 38,1 \\
\hline İmalat yapmiyor & 142 & 54,4 & 104 & 61,9 \\
\hline
\end{tabular}

Araştırma hipotezlerinin testinde öncelikle tüm gruplar için parametrik test koşullarının sağlanıp sağlanmadığı kontrol edilmiştir. Normalliğin değerlendirilmesinde Kolmogorov-Smirnov testinden yararlanılmıştır. Test sonucu elde edilen bulgulara göre her grup için normallik sağlanmıştır ( $>00,05)$. Buna göre hipotezlerin analizinde t-testi kullanılmıştır.

t-testinin uygulanabilmesi için iki grubun varyanslarının homojen olması gerekir. Varyans homojenliği için Levene testi yapılmış, test sonucu varyansları eşit olmayan gruplar için uygun olan test değeri kullanılmıştır. t-testi sonucu elde edilen bulgular Çizelge 5 'te verilmiştir.

Tablo 5. Hızlı Büyüyen ve Hızlı Büyümeyen KOBİ'lerin İç Girişimcilik Düzeylerinin Farklılık Testi

\begin{tabular}{|c|c|c|c|c|c|c|c|c|}
\hline $\begin{array}{l}\text { İç Girişimcilik } \\
\text { Boyutu }\end{array}$ & КОВі் & $\mathbf{n}$ & Ort. & $\begin{array}{c}\text { St. } \\
\text { Sapma }\end{array}$ & $\mathbf{t}$ & sd & $\mathrm{p}$ & Karar \\
\hline \multirow{2}{*}{ Yenilikçilik $^{a}$} & Hızlı Büyüyen & 261 & 4,12 & 0,86 & $-2,15$ & 307,04 & $0,03^{*}$ & H1 Kabul \\
\hline & Hızlı Büyümeyen & 168 & 3,91 & 1,04 & & & & \\
\hline \multirow{2}{*}{ Yeni Girişim $^{a}$} & Hızlı Büyüyen & 261 & 3,95 & 0,95 & $-1,52$ & 325,73 & 0,13 & H2 Red \\
\hline & Hızlı Büyümeyen & 168 & 3,80 & 1,07 & & & & \\
\hline \multirow{2}{*}{ Örgütsel Yenilenme } & Hizlı Büyüyen & 261 & 3,92 & 0,93 & $-1,91$ & 427,00 & 0,06 & H3 Red \\
\hline & Hızlı Büyümeyen & 168 & 3,73 & 1,06 & & & & \\
\hline \multirow[t]{2}{*}{ Proaktif Davranış } & Hızlı Büyüyen & 261 & 3,94 & 0,84 & $-2,18$ & 427,00 & $0,03^{*}$ & H4 Kabul \\
\hline & Hızlı Büyümeyen & 168 & 3,75 & 0,98 & & & & \\
\hline
\end{tabular}

a Levene testi sonucu varyanslar eşit bulunamadığından eşit olmayan varyanslara göre t testi yapılmıştır.

${ }^{*} \mathrm{p}<0,05$

Yapılan analizler sonucunda hızlı büyüyen ve hızlı büyümeyen KOBİ'lerde iç girişimciliğin yenilikçilik ve proaktif davranış boyutları açısından istatistiksel olarak anlamlı farklılıklar belirlenmiştir $(t=-2,15, p=0,03<0,05$, H1 kabul; $\mathrm{t}=-2,18, \mathrm{p}=0,03<0,05, \mathrm{H} 4 \mathrm{kabul})$. Diğer boyutlar olan yeni girişim ve örgütsel yenilenme açısından ise anlamlı bir farklılık bulunamamıştır ( $t=-1,52, p=0,13>0,05, H 2$ Red; $t=-1,91, p=0,06>0,05$, H3 Red).

Hızlı büyüyen KOBİ'lerin yenilikçilik boyutuna ilişkin ortalama değeri 4,12 iken hızlı büyümeyen KOBI'lerin 


\section{M. Öztürk Dugan - N. Tosunoğlu 12/2 (2020) 2061-2079}

ayn boyuta ilişkin ortalamaları 3,91 olmuştur. Bu sonuca göre yenilikçilik düzeyi yüksek olan işletmelerin hızlı büyüme gösterdiği söylenebilir.

Proaktif davranış boyutuna ilişkin ortalama değer hızlı büyüyen KOBİ'ler için 3,94 iken hızlı büyümeyen KOBI'ler için 3,75 olmuştur. Hızlı büyüyen KOBI’lerin proaktif davranışı daha çok sergiledikleri söylenebilir.

\section{SONUÇ}

KOBİ'lerin ulusal ekonomiler açısından; üretim artışı ve bunun getirdiği büyüme başta olmak üzere istihdam, istikrar, gelir dağılımı ve sosyal bütünlük gibi makro amaçlara önemli katkılar sağladığı görülmektedir. KOBI'ler ulusal pazarlarda da, topluluk pazarlarında da ekonomik gelişime sağladıkları yararlar bakımından endüstriyel yapının vazgeçilmez unsurlarıdırlar. Değişime açık ve uyum sağlayan yapıda olmaları nedeniyle ekonomilerde önemli yer tutmaktadırlar (Sevim ve Öncel, 2007). KOBI’ler, bir ülkenin sosyo-ekonomik yapısı çerçevesinde sanayileşme, sağlıklı kentleşme, milli gelirin eşit dağılımı ve dış ödemeler dengesinin dolaylı ve dolaysız ihracat yoluyla gelişmesine önemli katkılarda bulunmaktadır. Ayrıca, yurtiçi ürün talebinin karşılanması konusunda ülke ekonomilerine katkıda bulunma ve sahip oldukları esnek yapı ile ekonominin değişen koşullarına hızla uyum sağlayabilme özelliklerine sahiptirler. Yapılan araştırmalar KOBílerde istihdam edilecek bir çalışan için katlanılan maliyetin büyük işletmelere göre çok daha düşük olduğunu göstermektedir. Hızlı büyüyen işletmelerin bu sürece katkısı ise özellikle durgun ekonomik dönemlerde net istihdam artışına daha fazla katkı sağlaması yönüyle farklılaşmaktadır. Bu durum da KOBíler arasında hızlı büyüyen işletmelerin ayrıştırılarak bu işletmelere daha da özen gösterilmesi gerektiğini göstermektedir. Hızlı büyüyen KOBI'lerin ortak özellikleri arasında yeni müşteriler edinmeleri, yenilikçilikleri, yeni hizmetler geliştirmeleri ve yeni fırsatları daha erken tespit edebilmeleri yer alır. Bu açıdan incelendiğinde hızlı büyümenin işletmenin iç girişimcilik özellikleriyle ilişkili olabileceği düşünülmüştür.

Hızlı büyüyen KOBI'lerin iç girişimcilik düzeylerinin farklılığını incelemek amacıyla yürütülen bu çalışmada dört hipotez üzerine kurulu karşılaştırmalı nicel bir araştırma yapılmıştır. Ankara-KOSGEB veri tabanına kayıtlı KOBI'ler üzerinde yapılan araştırma sonucunda hızlı büyüyen ve hızlı büyümeyen KOBI'lerde yenilikçilik ve proaktif davranış için anlamlı farklılıkların ortaya çıtığı görülmüştür. Diğer iç girişimcilik boyutları olan yeni girişim ve örgütsel yenilenme boyutu için ise hızlı büyüyen ve hızlı büyümeyen KOBİ'lerin benzer eğilimde oldukları gözlenmiştir.

Sonuçlar değerlendirildiğinde Ankara ilinin sosyo-ekonomik koşullarında iç girişimciliğin proaktif davranış ve yenilikçilik boyutlarında öne çıkan KOBİlerin hızlı büyümesinin olası olduğu söylenebilir. Bu sebeple iç girişimciliğin devlet politikaları nezdinde de desteklenerek özendirici olması önem arz etmektedir. Bu destek hızlı büyüyen işletmelerin sayısının artmasını sağlayacaktır. Hızlı büyüyen işletmelerin sayısının artması ekonomide durgunluk dönemlerinde bile net istihdama katkı sağlayarak işsizliğin azalması, ülke ekonomisinin toparlanması, ihracatların artması gibi alanlarda katkı sağlayarak ekonomik iyileşmelere yardımcı olacaktır.

Yenilikçilik, yenilik yapabilmenin tek temel yeteneğidir. Girişimciliğin odak noktası ve hayati bir karakteristiğidir (Ağca ve Kurt, 2007). Proaktiflik ise geleceği kestirerek olayların arkasından gitme değil geleceği kestirerek ve etkileyerek olaylara yön vermedir (Koçel, 2005). Proaktiflik hızlı değişen çevresel şartlara ayak uydurabilmek ve bir adım öne geçebilmek amacıyla çevrenin gelecekteki taleplerini öngörerek potansiyel taleplere rakiplerden önce cevap verebilecek yapıda davranış biçimidir (Ağca ve Kurt, 2007). Buna göre işletmede yenilikçilik düzeyinin artması iç girişimcilik üzerinde doğrudan etkili olup hızlı büyümeyi etkileyecek ve iç girişimcilerin aktif olmalarını sağlayacaktır. Dinamik yapılı işletmelerin çevrede alışılamayacak ve olumsuz karşılanabilecek yenilikçi faaliyetlerinin ve süreçlerinin çevrenin benimsemesini beklemeden proaktif hareketlerle piyasada öncü olma girişimleri işletmelerin hızlı büyümesine daha yatkın olmasını sağlayacaktır.

İç girişimciliğin yeni girişim ve örgütsel yenilenme boyutlarında diğer iki boyuta göre daha fazla risk içeren sorular yer almaktadır. Bu boyutlarda farklılık çıkmaması, iç girişimcilerin daha riskli ve daha yönetsel sorularda çekimser kalabileceği algısını oluşturmaktadır.

Hızlı büyüyen KOBİ kavramıyla ilgili, ulusal literatürde sınırlı sayıda çalışma yer almaktadır (Taymaz ve diğerleri, 2008; Güzel ve Giray, 2014; Yücelen, 2017). Bu nedenle bu çalışmanın ulusal literatüre katkı sağlayacağ düşünülmektedir. 


\section{M. Öztürk Dugan - N. Tosunoğlu 12/2 (2020) 2061-2079}

Gelecek çalışmalarda hızlı büyüyen ve büyümeyen KOBİlerde iç girişimcilik düzeylerini karşılaştıran benzer araştırmaların yapılması ile konu daha ayrıntılı tartışılabilecektir. Bunun yanı sıra iç girişimciliğin diğer boyutları ile hızlı büyüyen işletmelerin içsel ve dışsal faktörleri arasındaki ilişkinin incelenmesi üzerine çalışmalar da konuya ilişkin farklı bulgular elde edilmesini sağlayacaktır. Aynı araştırmanın kapsamı Türkiye'de farklı şehirlerde yer alan KOBİlerden uygun örneklemler alınarak büyütülebilir. Buna ek olarak bu araştırmanın; farklı sektörler, çevresel etkiler ve kültürler bakımından incelenmesinin de yararlı olacağı düşünülmektedir.

Teşekkür: Araştırmanın veri toplama sürecindeki yardımlarından dolayı KOSGEB Strateji Geliştirme Daire Başkanlığına teşekkürlerimizi sunarız.

\section{KAYNAKLAR}

Adu-Darko, G. (2017). Entrepreneurial Leadership And Growth Of Small Medium Enterprises: Lessons From Transformational Entrepreneurs In Ghana. Doctoral dissertation, University of Ghana, Ghana.

Ağca, V. (2005). İç Girişimcilik Yapısı ve Firma Performansına Etkileri: Denizli Tekstil Sektöründeki Firmalarda Bir Uygulama. Yayımlanmamış Doktora Tezi. Afyon Kocatepe Üniversitesi Sosyal Bilimler Enstitüsü, Afyonkarahisar.

Ağca, V., ve Kurt, M. (2007). "İç Girişimcilik ve Temel Belirleyiciler: Kavramsal Bir Çerçeve". Erciyes Üniversitesi İktisadi ve İdari Bilimler Fakültesi Dergisi, 29, 83-112.

Ağca, V. ve Yörük, D. (2006). “Bağımsız Girişimcilik Ve İç Girişimcilik Arasındak Farklar: Kavramsal Bir Çerçeve" Afyon Kocatepe Üniversitesi, İ.I.B.F. Dergisi, VIII (2), 155-173.

Antoncic, B. (2007). "Intrapreneurship: A Comparative Structural Equation Modeling Study". Industrial Management \& Data Systems, 107(3), 309-325.

Antoncic, B., and Hisrich, R. D. (2003). "Clarifying the İntrapreneurship Concept”. Journal of Small Business and Enterprise Development, 10(1), 7-24.

Arslanoğlu, A. (2018). İçsel Pazarlama Uygulamalarının Hasta Güvenliği Kültürü Üzerine Etkisinde İç Girişimcilik ve Kişilik Özelliklerinin Düzenleyici Rolü. Yayımlanmamış Doktora Tezi, Haliç Üniversitesi Sosyal Bilimler Enstitüsü, İstanbul.

Atay, O. (2013). “KOBİ'lerde Araştırma ve Geliştirmenin Verimliliğe Etkisi ve Bir Uygulama”. Electronic Journal of Social Sciences, 12(47), 161-170.

Autio, E., Kronlund, M., and Kovalainen, A. (2007). High-growth SME Support Initiatives in Nine Countries: Analysis, Categorization, and Recommendations, Helsinki: Ministry of Trade and Industry, Industries Department, 1.

Bozkurt, Ö., ve Bozkurt, İ. (2008). "İş Tatminini Etkileyen İşletme İçi Faktörlerin Eğitim Sektörü Açısından Değerlendirilmesine Yönelik Bir Alan Araştırması". Doğuş Üniversitesi Dergisi, 9(1), 1-18.

Brown, R., and Lee, N. (2014). Funding Issues Confrontıng High Growth Smes in The UK. Edinburg: Institute of Chartered Accountants Scotland (ICAS).

Bjuggren, C. M., S.-O. Daunfeldt and D. Johansson (2013), "High-growth firms and family ownership". Journal of Small Business and Entrepreneurship, 26(4), 365-385.

Bulut, Ç., Fiş, A. M., Aktan, B., ve Yılmaz, S. (2008). “Kurumsal Girişimcilik: Kavramsal Yapı Üzerine Bir Tartışma". Journal of Yasar University, 3(10), 1389-1416.

Coad, A., Daunfeldt, S. O., Hölzl, W., Johansson, D., and Nightingale, P. (2014). "High-Growth Firms: İntroduction to the Special Section". Industrial and Corporate Change, 23(1), 91-112.Davidsson, P., Delmar, F., Wiklund, J. (2006). Entrepreneurship and the Growth of Firms. Edward Elgar Publishing, 65.

Davidsson, P., Delmar, F., Wiklund, J. (2006). Entrepreneurship and the Growth of Firms. Edward Elgar Publishing, UK. 
M. Öztürk Dugan - N. Tosunoğlu 12/2 (2020) 2061-2079

Dengiz, B., Belgin, Ö. (2007). KOBİlerin İş Süreçlerinde İnovasyon: Benzetimin Rolü. 4. KOBİler ve Verimlilik Kongresi Kongresi, 267-273.

Durmaz, I. (2011). Psikolojik Güçlendirme Algisinin İçgirişimcilik Üzerine Etkisi. Yayımlanmamış Doktora Tezi, Gazi Üniversitesi Sosyal Bilimler Enstitüsü, Ankara.

European Commission. (2009). European SMEs Under Pressure Annual Report on EU Small and Medium - Sized Enterprises 2009. Netherlands: EIM Business \& Policy Research.

Erkan, M. K. (2015). Firma Büyüme Performansının Dinamikleri. Yayınlanmamış Doktora Tezi, Sakarya Üniversitesi Sosyal Bilimler Enstitüsü, Sakarya.

Eyel, C. Ş., Ünkaya, G., ve Kaplan, B. (2019). “İktisadi Düşünce Tarihi Çerçevesinde Girişimcilik Kavramının Gelişimi". Istanbul Ticaret Üniversitesi Sosyal Bilimler Dergisi, 18(35), 557-586.

Ferrando, A., Pal, R., \& Durante, E. (2019). Financing and obstacles for high growth enterprises: The European case (No. 2019/03). EIB Working Papers.

Gershon, R. A., Kanayama, T. (2002). "The sony corporation: A case study in transnational media management". International Journal on Media Management, 4(2), 105-117.

Gülbahar, Y. (2019). Girişimcilik Tutkusunun Yenilikçi Davranışlar ve Başarısızlık Korkusu Üzerine Etkisi: Metanetin Aracıllk Rolü. Yayımlanmamış Doktora Tezi, Aksaray Üniversitesi Sosyal Bilimler Enstitüsü, Aksaray.

Gümüş, S. (2007). Haliç'teki KOBİ'lerin İhracatlarını Artırma Olanakları Üzerine Bir Araştırma. 4. KOBİ'ler ve Verimlilik Kongresi Kongresi, 237-249.

Günay, H. V. (2018). İşletmelerin Girişim Odaklilı̆̆ını Performansları Üzerindeki Etkisi ve Bir Uygulama. Yayımlanmamış Yüksek Lisans Tezi, İstanbul Ticaret Üniversitesi Sosyal Bilimler Enstitüsü, İstanbul.

Güney, S. (Editör). (2015). Girişimcilik: Temel Kavramlar, Girişimcilik Türleri, Girişimcilikte Güncel Konular, Ankara: Siyasal Kitabevi, 331.

Gürel, E. B. B. (2012). “İç Girişimcilik: Bir Literatür Taraması”. Gümüşhane Üniversitesi Sosyal Bilimler Enstitüsü Elektronik Dergisi, 3(6), 57-73

Güzel, S. ve Giray, F. (2014). “Hızlı Büyüyen KOBİler ve Bu İşletmelere Yönelik Destekler”. Ekonomi Bilimleri Dergisi, 6(1), 33-48.

Hacıevliyagil, N. (2016). “KOBI'lerin Finansman Sorununa Bir Çözüm Önerisi: Milli Ekonomi Modeli (MEM)”. Yönetim ve Ekonomi Araştırmaları Dergisi, 14(3 (Özel Sayı)), 32-50.

Heavey, C., Simsek, Z., Roche, F., and Kelly, A. (2009). “Decision Comprehensiveness and Corporate Entrepreneurship: The Moderating Role of Managerial Uncertainty Preferences and Environmental Dynamism". Journal of Management Studies, 46(8), 1289-1314.

Hevesli, T. T. (2016). Paylaşılan Liderliğin Değişime Açıklık ve İç Girişimcilik Üzerine Etkileri: Konya Gençlik Hizmetleri ve Spor İl Müdürlüğ̈̈̈nde Bir Araştırma. Yayımlanmamış Yüksek Lisans Tezi, KTO Karatay Üniversitesi Sosyal Bilimler Enstitüsü, Konya.

Huang, L. (2019). Canadian High-Growth SMEs and their Propensity to Invest in R\&D and Export. Ottawa, Canada: Innovation, Science and Economic Development Canada, 3.

Iraz, R., Çakıcı, A., ve Yılmaz, R. (2016). “KOBI'lerde Organizasyonel Becerilerin Yenilikçilik Performansına Etkisi: Konya İkinci Organize Sanayi Bölgesinde Bir Uygulama". The Journal of International Scientific Researches, 1(2), 52-67.

İçerli, L., Yıldırım, M. H., ve Demirel, Y. (2011). “KOBİlerde İç Girişimciliğin İncelenmesine Yönelik Bir Araştırma: Aksaray Örneği". Organizasyon ve Yönetim Bilimleri Dergisi, 3(2), 177-187.

Kalaycı, C. (2008). “Elektronik Ticaret ve KOBİlere Etkileri”. Uluslararası İktisadi ve İdari İncelemeler Dergisi, 1(1), 139-150.

Koçel, T. (2005). İ̧sletme Yöneticiliği. (10.basım). İstanbul: Arıkan Basım Yayım. 
M. Öztürk Dugan - N. Tosunoğlu 12/2 (2020) 2061-2079

Kozak, A. M., ve Yılmaz, G. E. (2010). “Otel Yöneticilerinin İç Girişimcilik Algılamaları: Frigya Bölgesi Örneği". Anatolia: Turizm Araştırmaları Dergisi, 21(1), 85-97.

Küçük ve Orta Ölçekli İşletmeleri Geliştirme ve Destekleme İdaresi Başkanlığı (KOSGEB). (2015). 2015 - 2018 KOBI Stratejisi ve Eylem Planı. Ankara: KOSGEB, 35-69.

Mason, G., Robinson, C., ve Bondibene, C. R. (2012). “Fast-Growing Firms, Product Strategies and Skills Development". NESTA, London, http://www. nesta. org. uk/library/documents/fastgrowingfirmswp. pdf.

Monteiro, G. F. A. (2019). "High-Growth Firms and Scale-Ups: A Review and Research Agenda". RAUSP Management Journal, 54(1), 96-111.

Moreno, A. M., and Casillas, J. C. (2007). "High-Growth SMEs Versus Non-High-Growth SMEs: A Discriminant Analysis". Entrepreneurship and Regional Development, 19(1), 69-88.

Naktiyok, A. (2004). İç Girişimcilik. İstanbul, Beta Yayınevi.

Naktiyok, A., ve Kök, S. B. (2006). “Çevresel Faktörlerin İç Girişimcilik Üzerine Etkileri”. Afyon Kocatepe Üniversitesi İktisadi ve İdari Bilimler Fakültesi Dergisi, 8(2), 77-96.

Nixon-Nicholls, C. L. (2005). "Rapid Growth and High Performance: The Entrepreneur's "Impossible Dream?"'. Academy of Management Executive, 19(1), 77-89.

OECD - Oslo Manual (2005). Proposed Guidelines for Collecting and Interpreting Technological Innovation Data, Paris.

Onay, M., ve Çavuşoğlu, S. (2010). “İşletmelerde Girişimcilik Özelliğini Etkileyen Faktörler: İç Girişimcilik". Yönetim ve Ekonomi: Celal Bayar Üniversitesi İktisadi ve İdari Bilimler Fakültesi Dergisi, 17(1), 47-67.

O'Regan, N., Ghobadian, A., and Gallear, D. (2006). “In Search of the Drivers of High Growth in Manufacturing SMEs". Technovation, 26(1), 30-41.

Organisation for Economic Co-operation and Development. (2010). OECD Studies on SMEs and Entrepreneurship High-Growth Enterprises: What Governments Can Do to Make a Difference. Paris: OECD Publishing, 16.

Öztürk, Ö. (2007). İstihdam Konusunda KOBİ'lerin Önemi Ve KOBİ Alanında Eğitim İstihdam İlişkisi Açısından Kamu İstihdam Kurumunun Rolü. Uzmanlık Tezi, Ankara.

Pinchot, G. (1985). Intrapreneuring, Harper and Row. New York.

Salavou, H., Baltas, G., and Lioukas, S. (2004). “Organisational İnnovation in SMEs: the İmportance of Strategic Orientation and Competitive Structure". European Journal of Marketing, 38(9/10), 1091-1112.

Seshadri, D. V. R., ve Tripathy, A. (2006). "Innovation through Intrapreneurship: The Road Less Travelled". Vikalpa: The Journal for Decision Makers, 31(1), 17-30.

Sevim, Ş., ve Öncel, M. (2007). Müzakereler Sürecinde KOBİlerin AB Fonlarından Yararlanması Üzerine Bir Araştırma, G. Gençyılmaz (Editör). 4. KOBİler ve Verimlilik Kongresi. İstanbul Kültür Üniversitesi Yayınları, 73-90.

Smallbone, D., Leig, R., and North, D. (1995). "The Characteristics and Strategies of High Growth SMEs". International Journal of Entrepreneurial Behavior \& Research, 1(3), 44-62.

Soydal, H. (2006). “Küçük ve Orta Büyüklükteki İşletmelerde E-ticaret”. Selçuk Üniversitesi Sosyal Bilimler Enstitüsü Dergisi, (15), 539-552.

Taymaz, E., Filiztekin, A., Fisunoğlu, M., Kılıçaslan, Y., Lenger, A. (2008). KOBİ'lerde Dönüşüm: Küçük Firmaların Büyük Başarıları, İstanbul: Türkonfed Yayınları, 7.

Tonge, R., Larsen, P. C., and Ito, M. (1998). "Strategic Leadership in Super-Growth Companies- A Reappraisal". Long Range Planning, 31(6), 838-847. 
M. Öztürk Dugan - N. Tosunoğlu 12/2 (2020) 2061-2079

Tüfekci, Ö. K., ve Tüfekci, N. (2014). “Pazarlama Yeniliği ile Pazarlama Performansı İlişkisini Açıklamaya Yönelik Bir Vaka Çalışması: Süleyman Demirel Üniversitesi Olimpik Yüzme Havuzu Örneği ve Bir Model Önerisi". Journal of Entrepreneurship \& Development/Girisimcilik ve Kalkinma Dergisi, 9(1), 162-179

Uçkun, N. (2009). “KOBI'lerin Finansal Sorunlarına Melek Sermaye Çare Olabilir mi?”. Muhasebe ve Finansman Dergisi, (41), 121-131.

Ulusoy, R., ve Akarsu, R. (2012). “Türkiye'de KOBI'lere Yapılan Destekler ve İstihdam Üzerindeki Etkileri". Kocaeli Üniversitesi Sosyal Bilimler Dergisi, (23), 105-126.

Usta, R. (2011). “Pazar Yöneliminin Firma Performansına Etkisini Güçlendiren Stratejik Yönelimler: Literatüre Dayalı Bütünsel Bir Model Önerisi". Anadolu Üniversitesi Sosyal Bilimler Dergisi, 11(3), 65-84.

Uzun, C. (2018). Alanya Otel İşletmelerinde İç Giriş̧imcilik Algıısı. Yayımlanmamış Yüksek Lisans Tezi, Gaziantep Üniversitesi Sosyal Bilimler Enstitüsü, Gaziantep.

Vértesy, D., Del Sorbo, M., and Damioli, G. (2017). High-growth, innovative enterprises in Europe. JRC Technical Reports. Luxembourg: Europen Union, 6.

Yazıcıoğlu, Y. ve Erdoğan, S. (2004). SPSS uygulamalı bilimsel araştırma yöntemleri. Ankara: Detay Yayıncılık.

Yener, S. (2019). "Örgütsel Yabancılaşma ve İç Girişimcilik Arasındaki İlişkide Psikolojik Rahatlık Algısının Düzenleyici Rolü". Hitit Üniversitesi Sosyal Bilimler Enstitüsü Dergisi, 12(1), 1-18.

Yıldırım, M. H., Demirel, Y., ve İçerli, L. (2011). “İşletme Sahibi Yöneticilerin Girişimci Kişilik Özellikleri İle Girişimcilik Becerileri Arasındaki İlişkinin Tespiti: Aksaray Örneği". Organizasyon ve Yönetim Bilimleri Dergisi, 3(2), 189-199.

Yılmaz, S., ve Bakan, İ. (2019). "Toksik Liderliğin Tükenmişliğge Etkisi: Bir Alan Araştırması". Kahramanmaraş Sütçü İmam Üniversitesi İktisadi ve İdari Bilimler Fakültesi Dergisi, 9(2), 1-12.

Yücelen, A. (2017). “Hızla büyüyen KOBİler büyüme dinamikleri ve performans analizleri”. Yayımlanmamış Doktora Tezi, Ankara Üniversitesi, Sosyal Bilimler Enstitüsü, Ankara. 